\title{
Тема номера
}

\section{5 иет Великой Победъ}

\section{РККА НАКАНУНЕ ВЕЛИКОЙ ОТЕЧЕСТВЕННОЙ ВОЙНЫ}

Гребенюк А.В.

В статье проведен анализ военно-технического состояния Красной армии накануне начала Великой Отечественной войны. Автор рассматривает проблемы, стоящие перед военным и политическим руководством СССР при проведении военных реформ, также анализирует просчеты советского руководства при реформировании структур РККА.

ричины военных неудач Красной Армии в начальный период Великой Отечественной войны всегда были в центре внимания историков. Высказываются различные точки зрения, а количество книг и статей по этому вопросу столь велико, что их простое перечисление заняло бы непозволительно большое место. В данном случае автор ставил перед собой достаточно скромную цель: рассмотреть состояние вооруженных сил СССР в соответствии с господствующей тогда военной доктриной, которая трансформировалась исходя как из внешнеполитической ситуации, так и субъективных факторов, связанных с внутрипартийной борьбой в Кремле. Важно взглянуть на истоки советской военной доктрины и, прежде всего, рассмотреть, какой потенциал средств для вооруженной защиты государства оставался у ленинского правительства вскоре после революции 1917 г.

В результате Брестского мира РСФСР лишилась Черноморского флота: лучшие боевые корабли были затоплены большевиками в Азовском море и в мелководной Цемесской бухте близ Новороссийска. Современный дредноут «Свободная Россия» (бывшая «Императрица Екатерина II Beликая») был торпедирован недалеко от Туапсе. Остальные военные суда во главе с новейшим отечественным линкором «Воля» (бывший «Император Александр ІІІ») ушли в оккупированные немцами порты Севастополь и Одессу고. Вице-адмирал В.К. Старк увел из Владивостока в Шанхай и Манилу тридцать военных кораблей Сибирской флотилии, где продал их за бесценок с аукциона².

Значительный ущерб оборонному потенциалу РСФСР нанесла и иностранная военная интервенция. Крейсеры «Варяг» и «Аскольд», и все эсминцы были на буксирах уведены в Англию³. Турецкие оккупанты привели из Батуми в Стамбул крейсер «Прут» и несколько эсминцев типа «Новик».

Балтийский флот, запертый в Финском заливе и лишенный подвоза топлива, оказался на приколе. По этой причине корабли Балтийского флота только числилась в строю Рабоче-крестьянского Красного Флота (РККФ), поскольку их команды были мобилизованы на сухопутный фронт как матросы речных и озерных флотилий, пехотинцы, артиллеристы бронепоездов и мотористы авиационных отрядов. В период гражданской войны в составе РККФ было создано 17 флотских формирований различного назначения, в которые входили обычные суда, наспех вооруженные полевой артиллерией. Командиры озерных и речных флотилий находились в подчинении командующих армиями, которые ставили им задачи на боевые действия по непосредственной огневой поддержке сухопутных войск. В состав таких флотилий входили

Гребенюк Андрей Владимирович - кандидат исторических наук, доцент Кафедры Всемирной и Отечественной истории МГИМО (У) МИД России, e-mail: grand@mgimo.ru. 


\section{5 лет Великой Победы}

малопригодные для ведения боевых действий торговые пароходы, самоходные баржи, землеотвозные шаланды, буксиры и болиндеры, на которые устанавливали полевые орудия. Они обозначались в документах как канонерские лодки, или мониторы. Тактика их применения в приказах характеризовалась точным кавалерийским термином «набег». Накопленный дорогой ценой опыт был объявлен прогрессивной революционной стратегией применения военно-морских сил, благодаря которой будут побеждены любые враги страны Советов ${ }^{4}$. Прославленные красные флотоводцы М.В. Викторов, К.И. Душенов, В.И. Зоф, И.К. Кожанов, С.В. Курков, И.М. Лудри, Р.А. Муклевич, Ф.Ф. Раскольников и В.М. Орлов так и не овладели навыками судовождения в океанских водах 5 .

Плохо обстояло дело и с красной авиацией. Крупнейший Русско-Балтийский военный завод (РБВЗ) в Петрограде, производивший четырехмоторные бомбардировщики «Илья Муромец", был закрыт по распоряжению секретаря Всероссийского Совета народного хозяйства Ю. Ларина. Ведущий конструктор Авиационного отдела РБВЗ И.И. Сикорский с большинством своих сотрудников эмигрировал во Францию, а затем в США. Профессиональные летчики-офицеры, происходившие из потомственной военной аристократии, после Октябрьского вооруженного восстания за малым исключением отказались служить Советской власти или вступали в ряды РККА для того, чтобы перейти потом на сторону противника. Но если в первое полугодие гражданской войны на сторону противника перелетело зо бывших офицеров, то в 1919 году такие случаи стали единичными ${ }^{6}$. Причина состояла в том, что в состав РККВФ стали призываться «нижние чины» Воздушного флота. Это были механики, мотористы и мастера по вооружению, которые чаще всего являлись пилотами, не получившими диплома военного летчика из-за своего происхождения. Многие знаменитые летчики первой мировой войны, сочувствовавшие революционным идеям, добровольно вступили в ряды Красной армии ${ }^{7}$.

Для победы в Гражданской войне руководству Красной Армии необходимо было грамотное управление войсками. Заметим, что на фоне обоснованной критики в адрес Л.Д. Троцкого, у него нельзя отнять главного качества руководителя умения находить нетрадиционные решения и подбирать талантливых и творчески мыслящих исполнителей. И, оставляя в стороне дискуссии о тоталитарных методах командования Красной армией как основной причине победы Советской России в гражданской войне, отметим, что огромную роль сыграла прогрессивная структура и организация воинских формирований РККА. Белым армиям противостояли маневренные воинские соединения РККА, которые успешно взаимодействовали с авиационными отрядами, подразделениями бронеавтомобилей и бронепоездами. В сентябре 1918 года в РККА были образованы постоянные фронты с соответствующими управлениями, штабами и политическими отделами, и в октябре в их составе действовали 14 регулярных советских армий. Конные армии были в отличие от иррегулярной казачьей конницы оснащены бронеавтомобилями, полевой артиллерией, пулеметными командами, самолетами и, конечно, знаменитыми тачанками. В Реввоенсовете РСФСР, в составе которого были «военные специалисты» из числа высших и старших офицеров Генерального штаба 8 , сделали упор на развитие новейших в то время средств борьбы - механизированную кавалерию, военную авиацию и «броневые силы», - и их массированное применение на стратегических участках фронта. Сама инфраструктура российских железных дорог давала редкую возможность применять одновременно несколько бронепоездов на участке оперативного прорыва обороны. Наиболее впечатляющими операциями таких дивизионов стали освобождение Ростова, Синельниково и Новороссийска9. Белогвардейские командующие, располагая сопоставимым количеством бронепоездов, так и не научились рационально их использовать.

В разгар гражданской войны по указанию Народного Комиссара по военным и морским делам и Председателя Революционного Военного Совета РСФСР Л.Д. Троцкого была создана Центробронь, позже реорганизованная в Совет броневых сил Советской Республики. Формируемые дивизионы оснащались бронепоездами и лучшими отечественными бронеавтомобилями высокой проходимости, которые серийно строились на Сормовском, Путиловском, Ижорском, Обуховском и Коломенском заводах. Один только Ижорский завод выпустил 115 бронеавтомобилей и отремонтировал 43 бронепоездов и броневагонов. Благодаря этому в строю Красной Армии к концу 1920 года находилось 123 бронепоезда и 50 броневых отрядов, по пять бронеавтомобилей в каждом, или 250 знаменитых «броневиков» ${ }^{10}$. В отличие от неприятельских, они применялись не для охраны коммуникаций и городов, а для усиления стрелковых подразделений в полевых условиях.

В строю Рабоче-крестьянского Красного Воздушного флота-РККВФ-числилось 430 разнотипных самолетов как иностранной, так и отечественной постройки. Командование социалистическими 
Гребенюк А.В.

авиационными отрядами (Авиадармом) сосредоточилось в руках одного из первых выпускников школы Фармана и большевика с дореволюционным стажем К.В. Акашева. Северо-западное управление возглавил Ю.В. Юнгмейстер, Восточное-А.В. Шиуков, Южное - И.И. Петрожицкий, Западное Н.Е. Шумский и Закавказское-И.В. Васильев, все профессиональные авиаторы довоенной формации ${ }^{11}$.

Самой сложной проблемой было отсутствие на складах Советской России качественного горючего для самолетов. Вместо бензина применялась так называемая «казанская смесь» из спирта, самогона, ацетона, бензола, одеколона, коньяка и дамских духов, реквизированных из национализированных технических складов, аптек и парфюмерных магазинов. Летно-технические данные советских самолетов оказались из-за этого невысокими. Этот коварный «авиационный коньяк», изготовленный по рецепту ученика Н.Е. Жуковского Б.И. Россинского, разъедал резиновые шланги бензопроводов и перкалевую обшивку крыльев, покрывал язвами руки мотористов и пилотов. «Смесь плохо сгорала, давала массу копоти, распространяла такую удушливую вонь, что через час-полтора полета болела голова. После полетов летчиков тошнило, - позже вспоминал комкор И.У. Павлов. - На газолине особенно рискованно было летать зимой. Если после взлета вы дали средние обороты, то в пути ни в коем случае их менять нельзя - мотор зальет и остановит. Тогда садись, где придется! Спирт-сырец как горючее был хуже и казанской смеси, и газолина. Зимой он плохо горел, влажнел и всегда имел большое количество воды, как бы тщательно ни заправляли самолет. После полетов на самолете, заправленном спиртом-сырцом, летчик страдал головными болями» ${ }^{12}$. По причине отсутствия каучука для шасси, самолеты «обували в лапти», о6матывая обода колес жгутами соломы и веревочными тросами.

В отношении красвоенлетов в течение всей гражданской войны действовал категорический приказ - «в плен красных летунов не брать!». Во время Лбищенской операции, в результате которой погиб легендарный начдив В.И. Чапаев, в плен к белоказакам попали и пилоты, летчики-наблюдатели и технический состав сразу 10 социалистических авиационных отрядов. По приказу адмирала А.В. Колчака были расстреляны без суда и следствия 300 «красных» пилотов, мотористов и техников ${ }^{13}$.

Не следует забывать, что их противниками были самые результативные российские асы ${ }^{14}$. В Крыму имелось 43 новейших английских многоцелевых двухместных самолетов Эйрко DH.4 и DH.9а и 25 современных британских истребителей. При 47-м авиационном отряде существовало Особое отделение «Б», где служили английские асы-истребители В. Андерсон, Д. Митчелл, С. Кинкейд, Р. Эдиссон и С. Фрогли ${ }^{15}$. Командующий военно-воздушными силами Добровольческой армии генерал-майор В.М. Ткачев позже пытался объяснить неудачи своих опытных летчиков в воздушных боях с красвоенлетами холопьим фанатизмом последних и их страхом перед ВЧК. Он так и не уяснил для себя простого факта, что организация применения военных самолетов требует их тщательной подготовки в штабах авиационных отрядов. А их в Крымской армии, как впрочем, и в авиации всех многочисленных знаменосцев «белого движения» создать не смогли. Шта6 РККВФ, напротив, создавал истребительные или бомбардировочные боевые авиационные группы на направлениях главного удара, располагая на фронте смешанными с точки зрения классов самолетами, которые были пригодны и для атаки наземных целей (штурмовки), и для бомбардировки долговременных сооружений, и для воздушного боя. По этому принципу была сформирована 1-я авиационная группа под командованием И.У. Павлова в количестве 170 боеспособных самолетов ${ }^{16}$. Самостоятельные боевые действия в Таврии осуществлял «Дивизион воздушных кораблей» в составе трех четырехмоторных бомбардировщиков «Илья Муромец», которым руководил Георгиевский кавалер А.В. Панкратьев. Само появление этих огромных самолетов, летевших на малой высоте, их мощные бомбовые удары вносили панику в ряды белогвардейской армии, особенно казачьей конницы и Дикой дивизии. На «Муромцев» возлагалась и дальняя воздушная разведка в глубине обороны противника. Впервые в практике воздушной войны тяжелые самолеты выполняли сугубо тактические задачи, что делало их бомбовую нагрузку беспрецедентной по объему ${ }^{17}$. Превосходство в воздухе окончательно перешло к советским пилотам. Во время наступления на Львов летчики 1-ой социалистической авиационной группы 1-ой Конной армии практически уничтожили лучшую 7-ю польскую эскадрилью имени Костюшко, укомплектованную американскими летчиками из знаменитого полка «Лафайет», и основательно потрепали опытных польских асов 2-го Великопольского авиационного полка ${ }^{18}$.

Умение Авиадарма РККА быстро наращивать силы на нужном участке тогда поставило в тупик и генерала В.М.Ткачева, и польское командование. Красная армия, и особенно ее авиация, в оперативном отношении оказалась гораздо сильнее, 


\section{5 лет Великой Победы}

нежели ожидали в европейских столицах ${ }^{19}$. Невероятные с точки зрения опыта первой мировой войны стратегические решения Главного штаба РККА и смелые тактические нововведения командующих фронтами зарубежные теоретики даже отождествляли с Армагеддоном - победой мирового зла над цивилизацией ${ }^{20}$.

Осенью 1920 года из-за потерь советского Западного фронта под Варшавой, понесенных от англо-французских танков, в РВС Республики впервые утверждается «Инструкция по применению танков в Рабоче-крестьянской Красной Армии». В ней перечислялись типы танков, массовое производство было желательным для завершения мировой революции. «Большие танки» должны были иметь массу в пределах 42 тонн, скорость движения - до 10 км/час, а в качестве вооружения одну скорострельную или автоматическую пушку и четыре пулемета. «Средние танки» весом 1720 тонн должны были развивать скорость 16 км/час и вооружаться 4-6 пулеметами. И, наконец, «малые танки» весом 13,5 тонн, вооруженные одной малокалиберной автоматической пушкой и тремя пулеметами, должны были двигаться по пересеченной местности со скоростью 18-22 км/час 21.

Прототипом первого советского танка послужил французский танк Рено FT.17. 18 марта 1919 года бойцами 2-й Украинской советской бригады Н.А. Григорьева под Одессой в бою у станции Березовка под Одессой были захвачены 4 исправных танка. Один из них отправили в Москву в качестве подарка В.И. Ленину ко дню рождения ${ }^{22}$. Остальные были отвезены в Харьков и включены в состав «Броневого дивизиона особого назначения имени Совнаркома Украины». Л.Д.Троцкий, осмотрев танк в Кремле, распорядился наладить на Сормовском паровозном заводе поточное производство легких танков для формирования первого в РККА бронетанкового отряда особого назначения.

Коллектив конструкторов технического бюро завода с сентября по декабрь 1919 года разработал чертежи новой машины «Красное Сормово», или КС-1. 15 дека6ря 1921 года, первый советский танк, под названием «Борец за свободу товарищ Ленин», покинул сборочный цех. КС-1 кроме усиленного вооружения отличался от французского образца автомобильным двигателем водяного охлаждения, шестигранной формой клепаной башни и 22-мм лобовой броней. Все серийные танки (всего 14 экземпляров) носили свои личные имена: «Парижская Коммуна», «Пролетарий», «Буря», «Победа», «Красный борец», «Илья Муромец», «Степан Разин», «Кузьма Минин», «Враг капитала», «Интернационал» и другие антиимпериалистические названия.
С завершением военных действий на Дальнем Востоке ихпроизводство было прекращено ввиду отсутствия необходимости ${ }^{23}$.

В мае 1921 года приказом РВС было создано Управление начальника броневых сил РККА для организации и руководства танковыми соединениями. Сформированная Отдельная эскадра танков явилась основой для становления бронетанковых сил РККА. В ее составе имелось 70 трофейных танков, захваченных красноармейцами на различных фронтах гражданской войны. Организационно она состояла из четырех флотилий: 1-й «тяжелотанковой», в которой по штату было 43 тяжелых английских танка Mk.V (командир флагман 1-го ранга Ф.М. Шибунин), 2-й «среднетанковой», включавшей в себя 12 быстроходных танков Mk.A «Уиппет» (командир - флагман 2-го ранга Л.П. Дьяков) и 3-й «легкотанковой» в составе 33 легких французских танков Рено FT.17 (командир - флагман 1-го ранга С.М. Тимофеев). Последняя 4-я «учебная флотилия» была укомплектована 54 тяжелыми бронеавтомобилями (командир - флагман 3-го ранга А.А. Поликарпов). Первые регулярные бронетанковые соединения были укомплектованы в основном матросами, которым после Кронштадского восстания в Политбюро ЦК РКП (б) не доверяли. Танковым флотилиям придавались трофейные мотоциклы, грузовые автомобили и бензозаправщики ${ }^{24}$. В Харькове эскадра за короткий срок была реорганизована в 10 танковых отрядов. Но их эксплуатация показала, что такие отряды могли эффективно обслуживаться только вблизи железнодорожных магистралей, и в автономном режиме существовать не могли ${ }^{25}$.

Согласно постановлению СТО и РВС РСФСР от 26 января 1921 года была образована «Комиссия для разработки программы-максимум воздухоплавания и авиастроительства при Главоздухофлоте». Результатом ее недолгой деятельности стал доклад заместителя председателя А.П. Розенгольца -начальника Транспортного отдела в Реввоенсовете Республики. В нем говорилось, что «за истекшее время Комиссией был выполнен ряд работ, важнейшие из которых сводятся к следующим положениям:

«Определено число средств воздушного боя, необходимых для выполнения заданий Главкома [РККА] в ближайшее трехлетие.

Разработан план заграничных закупок и развития русской авиапромышленности.

Разработано число и квалификация необходимых специалистов.

Разработан план подготовки специалистов и школьного строительства. 
Гребенюк А.В.

Определены основы местной организации Воздушного Флота.

Составлен план снабжения [РККВФ РККА].

Определены основные воздушные линии» ${ }^{26}$.

После приобретения лицензии на производство мощного американского авиационного двигателя CW-12а «Либерти» был создан массовый отечественный многоцелевой бомбардировщик Р1. В годы первой пятилетки в состав советских ВВС вошли 2924 этих надежных отечественных самолетов. Они использовались и как разведчики, и как штурмовики, и как артиллерийские корректировщики, и как поплавковые морские разведывательные гидросамолеты МР-1. «Я стал летчиком, - рассказывал один из старейших советских пилотов Михаил Каминский, - в те далекие годы и хорошо знаю, чем тогда была наша авиация. После трофейных "фарманов", "сопвичей", "фоккеров" и лицензионных "мартинсайдов" наши отечественные Р-1 считались верхом надежности. Однако это были очень строгие машины, и полеты на них казались пределом человеческого умения» ${ }^{27}$.

На XI съезде РКП(б) в январе 1922 года по предложению заместителя Председателя BCHX по военно-морским делам П.А. Богданова принимается новая оборонная доктрина ${ }^{28}$. Согласно этой концепции РСФСР отказывалась от наступательных вооружений. Личный состав Красной Армии приказом РВС был сокращен в десять раз до 500 ооо военнослужащих срочной службы. Все армейские управления РККА упразднялись, кадровый командный состав, в первую очередь «военспецы», увольнялся без права восстановления в прежних должностях, вся боевая техника подлежала сокращению, а военная промышленность - «демобилизации». Обе Конные армии фактически были преобразованы в кавалерийские корпуса. Бронепоезда большей частью демонтировались, бронеавтомобили переделывались в грузовые автомашины, а боеспособные танковые войска теперь согласно штатному расписанию состояли из 19 английских тяжелых танков Mk.V и одного командирского танка Mk.A «Уиппет». В основном, они предназначались для демонстрации «военной мощи страны Советов» на праздничных военных парадах на Красной площади в Москве.

1 мая 1922 года в Москве над Красной площадью прошел воздушный парад. В нем приняло участие $з о$ самолетов разнообразных типов и времени постройки. Колонна шла длинной извилистой лентой над Москвой-рекой, что производило тягостное впечатление на зрителей. Чтобы создать впечатление большого количества самолетов, командующий парадом Троцкий приказал пройти по одному и тому же маршруту несколько раз ${ }^{29}$.

После этого член Политбюро ЦК РКП(б) М.В. Фрунзе заявил на расширенном заседании РВС РСФСР: «Нужно, чтобы и теперь, несмотря на нынешнее затишье и отсутствие непосредственной опасности, раздался из уст партии новый лозунг: "Пролетарий, на воздушного коня". Надо помнить, что дело создания Воздушного флота 6олее трудное и сложное, чем создание конницы. Оно требует бдительной методической предварительной работы, поэтому и медлить нельзя. Даже при самой скромной оценке будущей роли Воздухофлота его значение будет на самом деле огромным. Мы с полной уверенностью должны признать, что всякое государство, которое не будет обладать мощным, хорошо организованным, обученным и подготовленным Воздухофлотом, неизбежно будет обречено на поражение» ${ }^{30}$. Троцкий не согласился с ним, заявив, что Красная Армия остается непобедимой благодаря революционному и классовому энтузиазму пролетариата первой в мире страны Советов. И.В. Сталин и К.Е. Ворошилов промолчали, но соответствующие выводы, вероятно, для себя сделали.

В дипломатических отношениях РСФСР с Францией, Великобританией и десятью новыми суверенными государствами Центральной и Восточной Европы сложилась непростая атмосфера взаимного недоверия и подозрительности. Присутствие на территории Польши, Литвы, Латвии, Финляндии, Румынии и Болгарии военизированных антисоветских формирований усугубляло ситуацию. Складывалось впечатление, что возможна вооруженная агрессия со стороны этих государств. В то же время количество наступательных вооружений, поступавших из Франции и Англии в армии этих государств, и размеры военных кредитов явно превышали их потребности. Вероятный военно-политический союз с Германией мог если не предотвратить новую интервенцию, то, во всяком случае, ее отсрочить. Во время Генуэзской конференции, в Рапалло, между Веймарской республикой и Советской Россией был подписан договор о взаимном сотрудничестве. Оба государства предоставили друг другу режим наибольшего благоприятствования в торговле и обмене специалистами. Два государства-«изгоя» неизбежно должны были сблизиться, чтобы выжить в экстремальных условиях. Сбывались пророческие слова премьер-министра Великобритании Д. Ллойд-Джорджа: «Величайшая опасность в данный момент заключается, по моему мнению, в том, что Германия может связать свою судьбу 


\section{5 лет Великой Победы}

с большевиками и поставить все свои материальные и интеллектуальные ресурсы, весь свой огромный организаторский талант на службу революционным фанатикам, чьей мечтой является завоевание мира для большевизма силой оружия. Такая опасность - не химера» ${ }^{31}$.

И.В. Сталин, занимая в тот период пост Генерального секретаря ЦК РКП(б), о будущих планах советско-германского сближения обычно узнавал прямо на заседаниях Политбюро или Исполкома Коминтерна. Публично он не отрицал возможности того, что немецкие пролетарии совместно с воинами Красной Армии осуществят «мировую революцию» в Западной Европе. Но историкам пока не удалось обнаружить письменных доказательств его уверенности в таком исходе событий, как, впрочем, и в обратном. Во всяком случае, повлиять на Председателя Политбюро ЦК РКП(б) и Генерального секретаря Исполнительного комитета Коминтерна Г.Е. Зиновьева или Председателя ОГПУ и Председателя ВСНХ Ф.Э. Дзержинского он не мог.

В Германию по условиям Рапалльского договора на металлолом были отправлены на буксирах недостроенные новейшие линкоры и крейсеры «Император Николай I», «Бородино», «Кинбурн», «Наварин», «Андрей Первозванный», «Император Павел I» и «Измаил». Вслед за ними последовали бронепалубные крейсеры «Рюрик»32, «Громобой», «Россия» и «Богатырь». Та же участь постигла в 1924 году крейсеры 1-го ранга «Баян», «Диана», «Паллада», «Адмирал Макаров», и миноносцы типа «Меткий». Ленинградские партийные функционеры, вдохновленные секретарем Ленинградского обкома ВКП(б) Г.Е. Зиновьевым, не поленились и подняли со дна подорванный английскими торпедами во время гражданской войны крейсер «Олег», а в Архангельске - разобрали броненосец «Полтава», чтобы отправить металл на немецкие предприятия. Из состава Черноморского флота были выведены и разрезаны на металл модернизированные накануне первой мировой войной эскадренные броненосцы «Святой Евстафий», «Иоанн Златоуст», «Память "Азова"», «Три святителя», «Ростислав», «Святой Пантелеймон», «Двенадцать апостолов», «Георгий Победоносец» и «Синоп», крейсер 1-го ранга «Адмирал Корнилов» и 60 миноносцев различного водоизмещения.

Председатель РВС РСФСР Л.Д.Троцкий тем самым свято исполнял требование В.И. Ленина, написавшего членам Политбюро ЦК РКП(б) из Горок письмо со словами: «Я думаю, что флот в теперешних размерах, хотя и является флотишкой,... все же для нас непомерная роскошь... Флот нам не нужен, а увеличение расходов на школы нужно до зарезу... Держать флот сколько-нибудь значительного размера нам, по соображениям экономическим и политическим, не представляется возможным»33. Главными, конечно, были политические соображения: металлолом был необходим для голодающих немецких рабочих, которые поддерживали коммунистов в Германии.

Флагманом советского Рабоче-крестьянского Красного флота стал эскадренный миноносец «Яков Свердлов», который для своего времени был самым быстроходным и прочным кораблем этого класса. На нем после модернизации впервые установили четырехтрубные торпедные аппараты и новые 120-мм орудия главного калибра. Он мог теперь соперничать даже с иностранными легкими крейсерами ${ }^{34}$.

Краснознаменный Балтийский флот по состоянию на 1925 год имел в строю 3 небоеспособных линейных крейсера «Гангут», «Севастополь» и «Петропавловск», легкий крейсер «Аврора», 5 эсминцев типа «Новик», канонерскую лодку «Красное Знамя» постройки 1897 года, 9 подводных лодок типа «Барс», деревянный колесный минный заградитель «Яуза», парусно-паровой фрегат «Ленсовет», учебный корабль «Комсомолец», парусный барк «Товарищ», и около тридцати вспомогательных военных судов. Штабным кораблем КБФ был пассажирский пароход «Свирь»35.

В составеЧерноморского флота находились легкий крейсер «Коминтерн» 36 , 4 эсминца типа «Новик», минные истребители типа «Беспощадный», отечественная подводная лодка «Политрук» и 4 субмарины американской постройки «А», 2 трофейных бронированных французских быстроходных сторожевых корабля «Гневный» и «Альбатрос», канонерская лодка «Интернационал», плавбаза подводных лодок «Березань» и 4 сторожевых корабля. Штабным кораблем начальника Морскими силамиЧерного моря И.К. Кожанова был американский колесный пароход «Красный моряк», не имевший даже приемно-передающей радиостанции. Команды флагмана флота обычно подавались флагами расцвечивания или сигнальщиками ${ }^{37}$.

Отношение к военно-воздушным силам в Политбюро ЦК РКП(б) было иным. Советские авиационные отряды целенаправленно довооружались голландскими, английскими и итальянскими военными самолетами. В условиях политической изоляции эта непростая задача выполнялась резидентами ОГПУ. На покупку «воздухоплавательных аппаратов» по решению Политбюро ЦК РКП(б) от 26 января 1921 года выделялось 3 миллиона золотых рублей ${ }^{8}$. В результате, к 1 декабря 1922 года 
Гребенюк А.В.

за 1218 ооо рублей было приобретено через советские торговые представительства и подставных лиц 1000 новых самолетов и 500 авиационных двигателей. На восстановление и развитие отечественного авиастроения крупных денежных сумм практически не выделялось. Об этом свидетельствует любопытное письмо заместителя председателя комитета Хозяйственной политики ВСНХ Г.И. Ломова, отправленное в ноябре 1922 года в Секретариат ЦК РКП(6): «Дорогой товарищ Ленин! Прошу Вас помочь рабочим Московского аэротехнического завода, ибо помочь через BCHX или другие организации здесь невозможно... Я прошу Вас от имени Комитета Хозяйственной политики сделать соответствующее распоряжение о выдаче заводу аванса в 200000 рублей, одобренное Авиационным Советом, без предварительного одобрения Контрактной комиссии. Все факты, сообщаемые здесь, проверены и сомнений не вызывают». Никакого документа «с проверенными фактами» к письму не прилагается, как будто Председателю Совнаркома они известны. В ленинской резолюции сказано, что «предписывается в виде исключения, не создавая прецедента, выдать аванс в двести тысяч рублей Московскому аэротехническому заводу без заключения Контрактной комиссии» ${ }^{39}$. Аэротехническим заводом, или ГАТЗ № 8, называлась небольшая мастерская по изготовлению деревянных авиационных винтов и лыжных шасси «Пропеллер». Деньги, судя по адресату, были потрачены для закупки дополнительной военной авиационной техники и оборудования за границей, если только лыжи не изготавливались из сандалового дерева.

Иначе обстояло дело с подготовкой немецких военных специалистов и производством германских военных самолетов, что оговаривалось протоколами Рапалльского мирного договора. 11 августа 1922 года было заключено «Временное соглашение о сотрудничестве рейхсвера и РККА», давшее Германии право создавать на советской территории военные объекты для проведения испытаний техники и обучения личного состава тех родов войск, которые Германии запрещалось иметь по Версальскому мирному договору.

Однако в Берлине под различными предлогами затягивали воплощение достигнутых договоренностей, выжидая, кто в Политбюро займет место тяжело заболевшего В.И. Ленина. И, хотя на кремлевском Олимпе уже существовала «руководящая тройка» Г.Е. Зиновьева, Л.Б. Каменева и И.В. Сталина, целью которой являлась борьба с политическими амбициями Л.Д. Троцкого, исход этого противостояния был достаточно неопределенным. Троцкий фактически совмещал сразу три важнейших в стратегическом отношении должности: Председателя РВС республики, Народного комиссара по военным и морским делам и наркома путей сообщения. Его симпатии к американским социально-политическим институтам и образу жизни были широко известны, как, впрочем, и его германофобия. Пока под его контролем оставалась Красная армия и вся транспортная инфраструктура страны Советов, и в отсутствие неукротимого энтузиаста улучшения советско-германских отношений В.И. Ленина, вопрос об их будущем становился проблематичным. Сплоченность партийного триумвирата также вызывала законные сомнения: слишком разные по своим теоретическим взглядам и внешнеполитическому опыту деятели оказались в его составе. Но в любом случае, авторитет Троцкого был неизмеримо выше, чем у всех троих вместе взятых. Для свержения «демона революции» был нужен равновеликий по заслугам военачальник - М.В. Фрунзе.

В январе 1924 года по решению «руководящей тройки» в Политбюро ЦК РКП(б) была создана партийная комиссия, которой поручалось изучить состояние дел в Наркомате по военным и морским делам. В нее вошли С.И. Гусев (председатель), К.Е. Ворошилов, Н.И. Подвойский, Г.К. Орджоникидзе, М.В. Фрунзе и Я.М. Шверник. Ее вывод оказался неутешительным: «Красной армии как организованной, обученной, политически воспитанной и обеспеченной мобилизационными запасами силы у нас в настоящее время нет ${ }^{40}$. И хотя эта оценка носила очевидный политический характер, Председатель Реввоенсовета Л.Д. Троцкий подал заявление об отставке.

М.В. Фрунзе, став Наркомвоенмором, немедленно приступил к осуществлению военной реформы. В результате Красная Армия получила штатную численность в 562 тысяч человек. В ее составе на кадровом положении находились 26 стрелковых дивизий, почти вся кавалерия, РККВФ и РККФ. Территориальные подразделения состояли из 36 стрелковых дивизий, трех национальных бригад, одной кавалерийской дивизии, отдельного дивизиона бронепоездов и подразделений местной самообороны.

Реформа началась с реорганизации штаба Воздушного флота. В декабре 1924 года А.П. Розенгольц был освобожден от должности начальника Управления РККВФ, и на его место назначили П.И. Баранова, известного М.В. Фрунзе по Среднеазиатскому бюро РКП(б). Его хорошо знали И.В. Сталин и К.Е. Ворошилов по совместной работе в Реввоенсовете Юго-Западного фронта 


\section{5 лет Великой Победы}

в период советско-польской войны. Однако лучшей рекомендацией являлась его откровенная неприязнь к Л.Д. Троцкому. Заместителем и помощником (начальником штаба) П.И. Баранова стал профессиональный российский авиатор, выпускник Казанского военного училища и Николаевской военной академии, закончивший в 1916 году Киевскую школу летчиков-наблюдателей, капитан царской армии С.А. Меженинов. Фундаментальное военное образование и солидный боевой опыт этого незаурядного человека позволили начать системную реорганизацию военной авиации Красной армии. С.А. Меженинову принадлежат первые серьезные теоретические работы о стратегии и тактике советской авиации, в которых был представлен анализ применения российских авиационных отрядов на Восточном фронте в первую мировую войну, хотя конкретные примеры черпались главным образом из опыта гражданской войны ${ }^{41}$. Впервые в работе Меженинова прозвучала мысль об эффективности «посадочных десантов» в оперативном тылу противника.

Новое руководство Управления РККВФ при перестройке структур отечественных ВВС отдавало приоритет многоцелевым самолетам непосредственной поддержки пехоты и истребителям. Затем следовали скоростные бомбардировщики, а замыкали эту структуру дальние бомбовозы. Именно в советских ВВС впервые появилась Отдельная штурмовая авиационная бригада, вооруженная легкими двухместными бомбардировщиками Р-1 с сильным вооружением из четырех пулеметов в батареях под нижними крыльями. Командовали этим уникальным соединением ВВС Киевского военного округа комбриг А.А. Туржанский и полковой комиссар А.В. Белов. На Киевских военных маневрах в 1929 году они продемонстрировали прекрасные результаты взаимодействия с наземными стрелковыми подразделениями и кавалерией ${ }^{42}$.

С целью организации производства цельнометаллических самолетов в Советский Союз была приглашена знаменитая фирма «Юнкерс», предложившая привлекательные проекты ${ }^{43}$. В Москве 29 января 1923 года был подписан протокол о предоставлении ей концессии в подмосковных Филях для производства цельнометаллических пассажирских и транспортных самолетов. В городке Кольчугино немецкие специалисты начали строить завод по производствугофрированного дюраля, или, как его называли в ЦК ВКП(б), «кольчугалюминия». Предприятие получило название «А.Б. Аэротранспорт», так как в интересах сохранения видимости миролюбивых намерений СССР было решено исключить упоминание одиозного имени Юнкерса в официальных документах, равно как и в наименованиях самолетов. Конструкторское бюро завода состояло из 1350 квалифицированных немецких инженеров и технологов. На предприятии было занято более 4 ооо советских рабочих и мастеров. Завод производил в большом количестве цельнометаллические одномоторные пассажирские и транспортные самолеты F.13. Coветский Союз получил от этой фирмы до 1927 года в счет арендной платы за концессию 130 самолетов из 291 всех построенных экземпляров. На московском заводе «Юнкерс» было произведено 30 трехмоторных самолетов Юнкерс G.24 - в Советском Союзе они назывались ЮГ-1. Их переоборудовали в авиационных мастерских в бомбардировщики, и они вошли в состав 1-й бригады тяжелых кораблей РККВФ Московского военного округа. Согласно секретному приложению Договора о концессии, фирма «Юнкерс» производила цельнометаллические бомбардировщики А-20, разведчики Н-21 и истребители С-22. Точное количество таких самолетов, построенных для Красной армии, неизвестно. Считается, что многие самолеты остались незаконченными. В Филях в присутствии правительственной комиссии во главе с Наркомвоенмором М.В. Фрунзе в 1925 году был торжественно отпразднован выпуск сотого серийного самолета Н-21. В официальных отчетахи налоговых документах фигурируют только гражданские машины, но сумма - 8 миллионов золотых рублей, уплаченная Государственным банком за всю продукцию фирмы, явно этому противоречит.

Одномоторными легкими бомбардировщиками Юнкерс Н-21 был полностью укомплектован 14й авиационный отряд Московского военного округа, поскольку, когда возникали проблемы с запасными частями, их можно было получать только в Филях. Таким образом, советские ВВС в 1927 году имели в своем составе три бомбардировочных авиационных эскадрильи, оснащенных цельнометаллическими самолетами, и один Отдельный истребительный отряд ${ }^{44}$.

Параллельно с массовым производством отечественных самолетов Р-1 производились массовые закупки военных самолетов всех классов в Нидерландах, Италии, Англии и Германии. К январю 1925 года их общее количество составило 1987 современных истребителей, одномоторных и многомоторных бомбардировщиков, разведчиков и гидросамолетов, что превышало суммарный парк боевых самолетов всех государств Восточной и Северной Европы. Опасаясь дальнейшего роста советской оборонной мощи, Лига Наций по инициативе Польши и Венгрии наложила в 1926 году 
Гребенюк А.В.

эмбарго на поставку СССР 750 уже оплаченных самолетов.

В качестве вынужденной меры Совет Труда и Обороны СССР принял решение выделить на капитальное строительство и приобретения оборудования существующих самолетостроительных заводов на три года 19,5 млн золотых рублей и довести годовое производство до 1500 самолетов и 1800 моторов при работе в одну смену. Совнаркому Советского Союза пришлось развивать национальную авиационную промышленность, перепрофилировать все пригодные для производства самолетов промышленные предприятия[45]. Все советские авиационные конструкторы получили государственные задания по проектированию отечественных бомбардировщиков, разведчиков и истребителей. На заводских аэродромах начались испытания самолетов отечественной конструкции. В серийное производство были запущены истребители конструкции Н.Н. Поликарпова ${ }^{46}$ и С.О. Сухого ${ }^{47}$.

Развернулась широкая кампания по сбору народных средств на строительство военных самолетов, организованная Обществом друзей Воздушного флота (ОДВФ). В результате, материальная часть РККВФ к 1928 году пополнился 6олее чем 400 именными самолетами, построенных исключительно за счет взносов предприятий и трудящихся всех советских республик.

Необходимо было начать массовую подготовку летно-подъемного и технического состава, с чем сами небольшие отечественные авиационные военные школы справиться не могли.

По инициативе М.В. Фрунзе, Председателя Совета труда и обороны СССР Л.Б. Каменева и П.И. Баранова в 1925 году создается добровольное молодежное общество содействия развития авиации и противохимической обороны - Авиахим, в 1930 году переименованное в Осовиахим. Лозунгом этой добровольной организации в годы первой пятилетки стал призыв: “Осовиахим опора мирного труда и обороны СССР!» В Советском Союзе за пятнадцать лет было подготовлено 5 миллионов летчиков, механиков, мотористов, штурманов, планеристов и парашютистов.

Новое руководство РВС СССР достигло с командованием рейхсвера и соглашения о постройке Ольгинского химического завода по производству нервнопаралитических газов на базе московского треста «Метахим». Тогда же было принято решение о создании военных училищ химической защиты «Томка» и «Берсоль» для обучения немецких курсантов. Под Казанью была открыта секретная танковая школа «КАМА». В ней прошли профессиональную подготовку более зоо германских специалистов высокого ранга ${ }^{48}$.

В 1924 году в Липецке была создана авиационная школа для подготовки германских пилотов и штурманов под условным наименованием «4-я Отдельная эскадрилья ВВС РККА». Она базировалась на одном аэродроме с советским учебным авиационным отрядом. Их обучение и переподготовка поручались опытным советским инструкторам. К моменту официального закрытия Липецкой авиационной школы 160 немецких курсантов были аттестованы как летчики, 100 человек - как летчики-наблюдатели и 45 человек - как военные инженеры 49 .

Наконец, проводились теоретические и практические занятия по десантированию автономных вооруженных специальных отрядов в тылу противника. Здесь немецкие слушатели осваивали две ставшие классическими методики: посадочный десант и выброску парашютистов. Подготовкой немецких парашютистов руководили комбриг Л.Г. Минов и полковник П.И. Гроховский. В апреле 1929 года три самолета ЮГ-1, пилотируемые немецкими курсантами под руководством комбрига М.А. Савицкого и К. Штудента, осуществили «посадочный десант» в количестве 45 красноармейцев с четырьмя пулеметами в тылу отряда басмачей в таджикском кишлаке Гарм. Это был первый в истории вооруженный десант с посадкой в тылу расположения противника, который в советской официальной печати никак не афишировался55. Надо полагать, этот опыт пригодился будущему инспектору воздушно-десантных войск «третьего рейха» генерал-лейтенанту Курту Штуденту в Северной Африке.

Отвечали за непосредственную подготовку германских учащихся в Советском Союзе заместитель Председателя ОГПУ И.С. Уншлихт, заместитель Председателя РВС РСФСР М.Н. Тухачевский, начальник IV Разведывательного Управления Штаба РККА Я.К. Берзин и заместитель Народного Комиссара обороны по военно-морским делам Р.А. Муклевич. Общее руководство финансовой деятельностью иностранных учебныхзаведений осуществлял Ф.Э. Дзержинский. Теоретическими занятиями и полевыми учениями во всех школах проводили видные советские полководцы гражданской войны И.П. Уборевич, Р.П. Эйдеман, В.К. Путна, В.В. Вострецов, В.К. Блюхер, А.И. Корк, А.И. Егоров, И.У. Павлов, Я.М. Фишман и И.Э. Якир, а также большинство начальников управлений Народного комиссариата обороны и Штаба РККА. Нет необходимости объяснять, почему эти люди одними из первых попали в число репрессированных руководителей Красной армии, тем более, что уже после XIV съезда 


\section{5 лет Великой Победы}

ВКП(б) в связи с развертыванием социалистической индустриализации И.В. Сталин стал высказываться резко отрицательно по поводу сохранения добрососедских отношений с социал-демократическим «ревизионистским» правительством Германии.

После кончины М.В. Фрунзе Народным Комиссаром по военным и морским делам и Председателем Революционного Военного Совета СССР решением СНК и ЦИК СССР был назначен К.Е. Ворошилов. С его приходом реформа Красной армии как совокупность необходимых мероприятий стала пересматриваться в пользу нанесения внезапного удара по всей полосе обороны противника с использованием стрелковых и кавалерийских подразделений, артиллерии, авиации и подвижных автобронетанковых бригад.

Заместитель начальника Штаба РККА командарм 2-го ранга В.К. Триандафиллов в 1929 году выступил на заседании Ученого Совета Военной академии имени Фрунзе с докладом о теории глубокой наступательной операции. Он считал, что «за десять послевоенных лет положение нашей страны сильно изменилось. Советский союз стал в результате победы социализма одним из сильнейших государств, с могучей, высоко технически оснащенной Красной армией, перешедшей из группы "восточноевропейских (по машинизации) в группу западноевропейских" армий... Глубокие и сокрушительные удары могут вывести из игры довольно быстро целые государственные организмы. По отношению к большим государствам эти удары могут привести к разгрому их вооруженных сил по частям, крупными пачками. Удары эти являются наиболее верным средством для быстрого истощения людских и материальных ресурсов противника, для создания объективно благоприятных условий для социально-политических потрясений в неприятельской стране... Глубокие и сокрушительные удары остаются одним из самых верных средств для превращения войны в войну гражданскую. Государства-лилипуты могут быть раздавлены одним ударом. Вот почему современное оперативное искусство не может отказаться от глубоких ударов на сокрушение. Правильная и мудрая политика в строительстве вооруженных сил должна обеспечить благоприятные условия для ведения войны этим методом» ${ }^{51}$. Проведение операции сводилось к тому, чтобы решить две основные задачи. Во-первых, было необходимо взломать фронт обороны противника одновременным ударом танков, артиллерии, пехоты и авиации на всю ее тактическую глубину, и, во-вторых, развить тактический успех, достигнутый при прорыве обороны, в оперативный немедленным вводом эшелона подвижных войск при изоляции авиацией района прорыва от подхода резервов противника. Для осуществления прорыва предполагалось сосредоточить на направлении главного удара превосходящие силы и средства пехоты и поддержать их массированным воздействием артиллерии, танков и авиации. Основной задачей эшелона атаки являлся прорыв обороны противника. Для развития успеха предназначалась подвижная конно-механизированная группа фронта. Военно-воздушные силы и воздушно-десантные войска намечалось использовать для непосредственного содействия сухопутным войскам при прорыве и для борьбы с подходящими резервами противника. Одновременного подавления всей глубины вражеской обороны предполагалось достигать непрерывными авиационными ударами по тылам, продвижением танков дальнего действия и пехоты с танками непосредственной поддержки, а также действиями механизированных и кавалерийских соединений. Помощник начальника Главного управления механизации и моторизации РККА, комкор К.Б. Калиновский считал, что «техническая эволюция танка, давшая ему большую подвижность, соединенную с достаточным запасом хода, превратила из узкотактического средства пехотной атаки в средство широкого оперативного размаха. Современный танк способен участвовать во всех фазах боя и операциях. Значительная часть их будет служить основой для создания самостоятельных механизированных соединений... Боевые свойства танков должны быть использованы в полной мере, и осуществить это возможно только в составе самостоятельного механизированного соединения, все части которого обладали бы приблизительно одинаковой подвижностью. Поэтому, не отказываясь от применения танковых систем в составе других родов войск, необходимо создавать специальные механизированные соединения» ${ }^{2}$.

В апреле 1931 года Триандафиллов был назначен заместителем наркома обороны и начальником Управления вооружений и технической подготовки РККА. Он занимал свой пост всего три дня и погиб в авиационной катастрофе. Вместе с ним ушли из жизни командующий Московским военным округом командарм 1-го ранга С.С. Вострецов и комкор К.Б. Калиновский. Тем не менее теория глубокой операции нашла последователей в лице Начальника Военной академии имени Фрунзе Р.П. Эйдемана и начальника вооружений РККА М.Н. Тухачевского. В январе 1941 года заместитель начальника Генерального штаба вермахта генерал-лейтенант Ф. Гальдер сделал запись о том, что произошло «интересное совпадение: все мои предложения по обеспечению секретности плана 
Гребенюк А.В.

"Барбаросса" фюрер с негодованием отвергал. Когда я попробовал мягко рассказать ему о "теории оперативной внезапности", не называя, разумеется, автора, он вдруг ухватился за нее и сказал, что в моих мыслях есть немало полезного»53. Эта теория легла в основу плана германского «блицкрига» против СССР.

В постановлении Политбюро ЦК ВКП(б) от 15 июля 1929 года «О состоянии обороны страны», предусматривалось усилить темпы работ по усовершенствованию техники Красной Армии. Нарком обороны К.Е. Ворошилов говорил: «Пятилетний план народного хозяйства должен исходить из неизбежности вооруженного нападения на СССР и, следовательно, из необходимости в меру материальных ресурсов организации такой обороны Советского Союза, которая обеспечила бы победоносный отпор объединенным силам наших вероятных противников. Индустриализация страны предопределяет обороноспособность СССР. Но именно поэтому военные соображения должны внести свои коррективы в конкретные планы промышленного строительства. В частности:

а) районирование промышленности должно соответствовать требованиям стратегической безопасности;

6) металлургия, черная и особенно цветная, уже в ближайшие годы должна обеспечить минимальные потребности обороны;

в) общий план развертывания промышленности должен предусмотреть вложение достаточных средств в те отрасли, которые являются наиболее узкими местами в нашем хозяйстве и обороне (авто- и тракторостроение, химия и т.п.)» ${ }^{54}$.

В годы первых пятилеток авиации в СССР отдавался один из самых главных приоритетов. Еще в 1925 году состоялся первый групповой перелет Москва -Улан-Батор - Пекин под лозунгом «Наш пилот, наш самолет, наш мотор - из Москвы до Китая через Улан-Батор!» В нем приняли участие 5 отечественных самолетов и один Юнкерс $\mathrm{H}-21$. Общие расчеты, административное, техническое и эксплуатационное обеспечение экипажей на маршруте осуществлял начальник учебных заведений РККВФ И.П. Шмидт, исполнявший обязанности политического комиссара Липецкой авиационной военной школы. Германские газеты немедленно отреагировали на это сообщение, утверждая, что только благодаря нему состоялся этот евразийский перелет. Флагманский «юнкерс» первым потерпел аварию, и Шмидт был отозван в Москву. Он был награжден орденом Красного Знамени и немедленно откомандирован в Кемерово на педагогическую работу, что означало пожизненную ссылку. П.И. Баранов и С.А. Меженинов сделали из этого правильные идеологические выводы. В ознаменование 10-й годовщины Великой Октябрьской социалистической революции в 1927 году летчиком М.М. Громовым и бортмехаником Е.В. Радзевичем был осуществлен перелет на отечественном цельнометаллическом самолете АНТ-3 «Пролетарий» конструкции А.Н. Туполева по маршруту Москва - Кенигсберг - Берлин-Прага-Варшава-Москва. Международный эффект от перелета не заставил себя долго ждать. Французский еженедельник «L'illustracion», подводя итоги этого европейского турне, отметил: «СССР сегодня имеет авиацию с однородным составом персонала и моделей самолетов, причем эти самолеты-новых типов... Причиной этого является активность и результаты массовой авиационной пропаганды в Советской России» 55 .

С 10 июля по 8 сентября 1929 года на трехмоторном цельнометаллическом пассажирском самолете АНТ-9 «Крылья Советов» экипаж летчика М.М. Громова совершил международный перелет по маршруту Москва - Берлин - Париж - Рим Марсель-Невер-Лондон-Париж-Берлин-Варшава - Москва. Этот рекорд был персонально посвящен пятидесятилетию со дня рождения «вождя мирового пролетариата» Сталина. Английский авиационный журнал «Flight» в этой связи писал: «Как показывают летные данные АНТ-9, самолет этот делает честь конструктору и Советской России. Полет Громова по европейским столицам способствовал поднятию престижа русской авиации» ${ }^{56}$.

Самым значительным авиационным событием в этом юбилейном году стал перелет в США. На двухмоторном самолете АНТ-4 конструкции А.Н. Туполева под названием «Страна Советов» 30 октября 1929 года экипаж в составе летчиков С.А. Шестакова иФ.Е. Болотова, штурмана Б.В. Стерлигова и бортмеханика Д.Ф. Фуфаева совершил с невероятными трудностями перелет из Москвы в НьюЙорк. Этот трансокеанский полет доказал, что отечественная конструкторская мысль стала «законодателем моды» в мировом тяжелом самолетостроении. Журнал «Aviation», отдав дань мужеству и опыту экипажа, сделал знаменательный вывод: «Достигнув Нью-Йорка, советский самолет установил первый официальный контакт между США и СССР. ...Мы собираемся изучить самолет с интересом, как оригинальный продукт русской национальной авиационной промышленности, о которой мы, американцы, знаем слишком мало. Мы рукоплещем перелету... Нигде в мире признаки бомбардировщика не были столь полно и удачно объединены в одном самолете»57. 


\section{5 лет Великой Победы}

Поэтому нельзя считать случайностью, что И.В. Сталин занялся вопросами укрепления воздушной мощи СССР после этих международных перелетов.

В середине июня 1931 года был организован закрытый смотр военных самолетов на Центральном аэродроме. П.И. Баранов и командир авиационной бригады НИИ РККВФ комбригА.А. Туржанский выставили на Ходынском поле новые отечественные истребители, отечественные разведчики, голландский одномоторный бомбардировщик Фоккер C.IV и французский многоцелевой самолет Потез Ро.XXV. «Гвоздем программы» был опытный советский четырехмоторный бомбардировщик ТБ-3, на знакомстве с которым сосредоточили свое основное внимание И.В. Сталин, В.М. Молотов и Г.К. Орджоникидзе. Сталин даже пожелал совершить ознакомительный полет на этом самолете, что категорически запрещалось инструкциями. В ответ на решительный отказ Баранова, Сталин упрекнул его в том, что тот мыслит категориями прошлого, увлекаясь одномоторными самолетами, и потребовал немедленно запустить в производство четырехмоторный бомбардировщик ТБ-з ценой сокращения выпуска первых $5^{8}$. После этого инцидента П.И. Баранов был переведен на работу в Наркомат тяжелой промышленности ${ }^{59}$.

В Советском Союзе развернулось крупносерийное строительство тяжелых бомбардировщиков стратегического назначения ТБ- $3^{60}$, которые оказались действительно универсальными многомоторными самолетами. Во время летных испытаний бомбардировщика старший летчик А.Ф. Анисимов стал выполнять над аэродромом боевые развороты, горки и глубокие виражи. Никаких существенных деформаций фюзеляжа, хвостовой части и крыльев после полета специалистами обнаружено не было ${ }^{61}$. Самолетов ТБ-з различных версий, включая АНТ-6 «Авиаарктика», было построено 818 штук.

Начальником Главного управления ВВС РККА был назначен Я.И. Алкснис - патриот развития тяжелой бомбардировочной авиации и широко известный советский летчик-рекордсмен. В силу невысокой теоретической подготовки и небольшого опыта командной работы, он буквально воспринял замечание Сталина и начал ревизию прежней рациональной самолетостроительной программы. Серийное производство тяжелых бомбардировщиков получило «зеленый свет», а испытания и производство самолетов других классов финансировались по остаточному принципу. По причине инертности мышления и технической безынициативности Я.И. Алксниса, окончательное перевооружение всех истребительных советских авиационных соединений с окончательно устаревших тихоходных бипланов И-5 на скоростные монопланы И-16 завершилось только к началу 1939 года.

При всем своем уважении к тяжелой авиации И.В. Сталин отнюдь не считал ее универсальным средством обеспечения обороноспособности страны. Он считал необходимым создать в Ледовитом океане комплекс научно-исследовательских станций, чтобы иметь долгосрочные прогнозы движения воздушных масс в восточной Европе в случае начала империалистической агрессии. Поэтому в январе 1932 года в Москву из Италии был приглашен известный конструктор дирижаблей и полярный исследователь У. Нобиле. В поселке Долгопрудный под Москвой началось строительство завода по производству полужестких дирижаблей. Нобиле получил 80 инженеров для своего исследовательского центра и возглавил Учебный комбинат Дирижаблестроя-УКД. В ряды студентов было зачислено сразу 500 человек. В Совнаркоме СССР конструктору выделили деньги на постройку трех полужестких дирижаблей объемом от

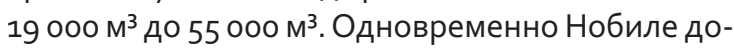
лжен был представить проект жесткого дирижабля объемом свыше 100 ооо м³. В серийном варианте они предназначались для военных целей как бомбардировщики. Они должны были летать на большой высоте, недоступной для истребителей противника. За короткий срок были построены полужесткие дирижабли В-1, В-2 и В-3, а в 1933 году - В-6. На последнем летательном аппарате осенью 1934 года был установлен мировой рекорд длительности полета по замкнутому круговому маршруту. Достижения германского дирижабля LZ.127 «Граф Цепеллин», пересекшего Атлантический океан, были перекрыты. В советской печати было объявлено, что советские дирижабли - лучшие в мире. 4 октября был объявлен праздничным днем Сталинского дирижаблестроения и был негласно отменен через три года после высадки с помощью самолетов на Северный полюс экспедиции И.Д. Папанина. УКД передали в распоряжение наркомата авиационной промышленности. Нобиле уехал в США ${ }^{62}$.

Между тем, с приходом нацистов к власти началось стремительное обострение советско-германских отношений. В воздухе запахло грядущей войной с Германией. Перед руководством СССР стояли непростые проблемы укрепления обороноспособности государства перед лицом технически совершенного противника. И за последующие несколько лет в этом отношении было сделано немало, в частности в области авиастроения. 
Гребенюк А.В.

В 1936 году на вооружение ВВС РККА поступили скоростные двухмоторные бомбардировщики СБ2 конструкции А.Н. Туполева с убирающимися шасси. Как показал опыт их применения в Испании, они не имели себе равных по максимальной скорости и потолку не только среди самолетов своего класса, но и среди большинства современных одномоторных истребителей. В Китайской Республике в период японской агрессии СБ-2 составляли костяк китайской бомбардировочной авиации. Они совершили дальний налет на остров Тайвань 23 февраля 1938 года. Эти самолеты производились по лицензии в Чехословакии под индексом Авиа В71 «Катюша», которые экспортировались и в Болгарию под названием «Жерав».

Советская истребительная авиация была оснащена бипланами И-15 и И-15бис с мощным пулеметным вооружением и монопланами И-16. «Спроектированный почти в то же время, что и самолет И-15, истребитель И-16 по своей базовой концепции уже являлся самой современной машиной своего времени - пишет английский историк Б. Ганстон. - Это был первый советский истребитель-моноплан неповторимой оригинальной конструкции с низко расположенным крылом и убирающимися в полете шасси. К изумлению западных специалистов, его скорость была на 100150 км/час выше, чем у всех истребителей других государств, а по маневренности и скороподъемности он превосходил аналогичные самолеты своих противников. Они успешно воевали в Испании и Китае, а с более мощными двигателями могли противостоять германской авиации и в начале гитлеровской агрессии» ${ }^{63}$. В течение шести лет И-16 постоянно модифицировался и долгое время являлся лучшим и самым быстроходным истребителем мира, пока не появились английские «спитфайры» и немецкие истребители Мессершмитт Bf-10gE.

Новые задачи обороны морских границ СССР также требовали принятия кардинальных решений. Пути дальнейшего развития военно-морских сил были изложены еще в докладе М.В. Фрунзе «Итоги и перспективы военного строительства» 17 ноября 1924 года. Он заявил, что «Реввоенсовет твердо и незыблемо стоит на той точке зрения, что флот нам крайне необходим, что мы должны его развивать и дальше, но мы упираемся сейчас в основной вопрос - программу нашего морского строительства» ${ }^{64}$. Новая доктрина развития РККФ в оперативно-тактическом плане носила оборонительный характер.

Для капитальной модернизации и перевооружения всех крупных боевых надводных, подводных и вспомогательных военных кораблей были реконструированы и построены 36 новых кораблестроительных заводов. Оставшиеся в России недостроенные в период первой мировой войны легкие крейсеры ранее предполагалось переделать в нефтеналивные суда. Успели построить два танкера «Азнефть» и «Грознефть», небольших по грузоподъемности и платной нагрузке. Три легких крейсера, оставшиеся на заводских стапелях в различной степени готовности, теперь решили достроить и модернизировать. После спуска на воду их назвали «Червона Украина», «Профинтерн» и «Красный Кавказ» ${ }^{65}$.

К 1937 году были радикально модернизированы линейные крейсеры «Гангут», «Петропавловск» и «Севастополь», войдя в состав советского военно-морского флота под новыми названиями «Октябрьская Революция» ${ }^{66}$, «Марат» и «Парижская Коммуна». Орудия главного калибра этих кораблей отличались уникальными баллистическими характеристиками, высокой точностью и дальностью стрельбы. Несмотря на сравнительно небольшое стандартное водоизмещение, 305-мм артиллерийские орудия главного калибра, облегченные броневые пояса и малый запас автономного хода, они идеально подходили для военных действий в мелководных северных морях. Хотя по советской классификации эти корабли считались линкорами, они, конечно, уступали современным линейным кораблям США, Великобритании, Франции, Японии и Германии, но превосходили броненосцы береговой обороны вероятных противников по всем показателям.

В ряду лучших кораблей своего класса находились новые легкие крейсеры итальянской постройки «Киров», «Ворошилов» «Молотов» и «Максим Горький». Немецкие специалисты относили их к классу тяжелых крейсеров из-за их скорости и скорострельности 180-мм орудий главного калибра ${ }^{67}$. Крейсеры «Киров» и «Максим Горький» вошли в состав Краснознаменного Балтийского флота. Однотипные военные корабли «Ворошилов» и «Молотов» стали флагманами отрядов легких сил на Черноморском флоте. На борту каждого модернизированного линкора и легкого крейсера находилось по два разведывательных гидросамолета КОР-1.

Вместе с модернизированными легкими крейсерами «Красный Кавказ», «Червона Украина» и «Профинтерн» Черноморского флота советские корабли этого класса представляли собой грозную маневренную крейсерскую эскадру. Она была способна решать самостоятельные боевые задачи даже в океанской акватории при создании большого нефтеналивного флота. Но, к сожалению, этого оперативными планами Наркомата 


\section{5 лет Великой Победы}

обороны не предусматривалось. Крейсеры целенаправленно готовились к «набегам» на порты и военные базы противника и высадке десантов на его территории.

Модернизированный учебный крейсер «Коминтерн» в случае войны мог выполнять функции артиллерийского корабля береговой обороны ${ }^{68}$. После коренной модернизации на корме «Коминтерна» установили закупленный в Германии гидросамолет КР-1, который спускался на воду со специального съемного металлического ската на корме.

И.В. Сталин, по воспоминаниям наркома Военно-морского флота Н.Г. Кузнецова, считал одной из важнейших задач долгосрочной судостроительной программы постройку мощных линкоров и тяжелых крейсеров. Никаких возражений против своей точки зрения он не признавал, считая сохранение «москитного» военно-морского флота вредной «ревизионистской троцкистской идеей». Он неоднократно заявлял на заседаниях Высшего Военного Совета РККА: «Хоть по копеечке соберем, но построим настоящий флот!»69. K июлю 1942 года он рассчитывал спустить со стапелей тяжелые крейсеры «Кронштадт» и «Севастополь», легкие крейсеры «Чапаев», «Чкалов», «Железняков», «Фрунзе», «Орджоникидзе», «Свердлов» и «Куйбышев», вспомогательный крейсер «Микоян», и линкор «Советский Союз» ${ }^{70}$. Уже тогда специалисты из Штаба РККФ и Военноморской академии высказывали сомнения в целесообразности этой программы, равно как в производственных возможностях советских судостроительных предприятий. Оставалось вопросом, где предстоит оперировать судам. В акватории Черного моря они были уязвимы, поскольку она полностью контролировалась морской и сухопутной авиацией вероятного противника. В мелководном, изобиловавшем мелями Балтийском море это обстоятельство усугублялось сложным характером фарватеров - даже линкорам «Октябрьская Революция» и «Марат» было чрезвычайно сложно маневрировать в его водах. Новые линкоры типа «Советский Союз» с полной боевой нагрузкой не могли пройти проливы Каттегат и Скаггерак из-за значительной осадки. Однако никаких изменений в Морские наставления внесено не было. Исправлять подобное положение пришлось уже в начале Великой Отечественной войны. Адмиралтейство Великобритании на условиях ленд-лиза передало Северному флоту старый линкор «Ройал Соверен», вошедший в его состав под названием «Архангельск» ${ }^{11}$. По своим ходовым характеристикам он соответствовал советским линкорам, один из которых был так необходим для обеспечения безопасности полярных конвоев.

В 1939 году в состав ВМФ вошли принципиально новые скоростные многоцелевые военные корабли итальянской постройки, созданные по советским проектам. Это были лидеры эскадренных миноносцев «Москва», «Ленинград», «Ташкент», «Харьков», «Минск», «Тбилиси» и «Баку» ${ }^{72}$, которые предназначались для стремительного прорыва в боевые порядки кораблей противника и нанесения по ним мощных артиллерийских и торпедных ударов. Благодаря установке мощных отечественных двигательных установок и крупнокалиберных артиллерийских орудий они стали лучшими кораблями своего класса в мире. Ходовые испытания головного корабля этой серии «Ташкент» продемонстрировали его отличную мореходность и очень высокую для эсминцев максимальную скорость с полной боевой оснасткой - 45 Узлов! В годы Великой Отечественной войны советские моряки прозвали его «голубым крейсером» за характерную окраску корпуса. Лидеры эсминцев по мере спуска на воду поэтапно вводились в состав основных военно-морских флотов Советского Союза. Их не спешили отправлять на небольшую Северную морскую флотилию (позже преобразованную в Северный флот). В Политбюро ЦК ВКП(б) бытовало мнение, что на этом стратегическом направлении по причине сложных климатических условий Заполярья активных военных операций не будет. В ее составе находились эсминцы «Валериан Куйбышев», «Петр Войков», «Карл Либкнехт» и 5 новых эсминцев проектов № 7 и № $7 Y^{73}$.

К январю 1940 года ВМФ СССР включал в себя 19 модернизированных эсминцев типа «Новик» ${ }^{74}$ и 32 современных корабля этого класса серии «Гневный» ${ }^{75}$ и «Гремящий» ${ }^{76}$. Как выяснилось, они уступали «новикам» в прочности77. Наряду с эсминцами оборону стратегических портов обеспечивали 19 миноносцев, 26 канонерских лодок, 22 больших сторожевых корабля и «морских охотника», 8о минных тральщиков и 120 торпедных катеров. На крупных российских реках и озерах, на Белом и Азовском морях оперативное дежурство несли дивизионы из 89 бронекатеров.

На Тихоокеанском флоте в строю находились 10 эсминцев, в том числе 3 корабля серии «Новик» и 5 новых кораблей этого типа, во главе с лидерами эсминцев «Баку» и «Тбилиси», 8 минных заградителей типа «Гром», 3 больших тральщика типа «Баклан» и 73 подводных лодки. В 1942 году «Баку» и все эсминцы серии № 7 были переведены Северным морским путем в Архангельск. 
Гребенюк А.В.

Военно-морской флот СССР к началу немецкофашистской агрессии располагал основным классом подводных лодок, представлявших реальную опасность для крупных боевых кораблей и транспортов противника, - 88 отечественными дизельными субмаринами средней дальности типа «Щ» («Щука»). Они в разных модификациях вооружались шестью 533-мм торпедными аппаратами и носовым 45-мм зенитным орудием с высоким углом возвышения впереди рубки. Запас хода «щуки» на экономической скорости в надводном положении составлял 3130 морские мили. В годы войны они вынесли на себе основную тяжесть подводной войны с германским флотом ${ }^{78}$.

78 подводных лодок типа «М» малого водоизмещения могли применяться лишь как средство дальнего обнаружения судов противника и торпедирования или обстрела из надводного положения небольших небронированных десантных транспортов из носовых 45-мм зенитных орудий. Теоретически во время войны активных наступательных действий «малютки» выполнять были не в состоянии ни в акваторииЧерного, ни Баренцева моря из-за их больших глубин. Но накануне войны усилиями советских морских инженеров удалось повысить дальность XII серии этих лодок до 3000 морских миль, а скорость - до 14 узлов в надводном и 8 узлов - в подводном положении. На них были установлены по два носовых торпедных аппарата, но без значительного запаса торпед. Стрельба из них должна была быть поистине ювелирной по точности, так как часто «малютки» после залпа теряли остойчивость. Благодаря беспримерному мужеству советских моряков и их профессиональной подготовке «малютки» в годы Великой Отечественной войны стали грозной силой в борьбе с вражескими конвоями на Балтийском и Черном море ${ }^{79}$.

Подводные лодки океанского класса серий «Д», «C ${ }^{80}$ и «К» ${ }^{81}-58$ «подводных крейсеров», обладали большой дальностью хода, мощным торпедно-артиллерийским вооружением и солидным водоизмещением. Минные заградители серии «Л» строились по лучшим зарубежным английским проектам. Лучшими подводными кораблями были отечественные субмарины типа «К», которых моряки любовно назывались «касатками». Менее удачными были эскадренные субмарины серии «П», которые по причине конструктивных органических недостатков для действий на средних глубинах вошли в состав КБФ в количестве 12 серийных экземпляров ${ }^{82}$.

После XVIII партийного съезда Советским правительством были все-таки выделены дополнительные средства и для постройки авианосца, хотя
Сталин не считал это первостепенной задачей. В Генеральном штабе считали, что выгодное географическое положение СССР позволит использовать развитую сеть аэродромов на побережье для уничтожения флота противника. Тем не менее, наЧерноморском Морском заводе в 1939 году был заложен авианесущий корабль водоизмещением 55 ооо тонн, обозначенный в официальных документах из соображений секретности «линейным крейсером "Советская Украина"». Так, во всяком случае охарактеризовали остатки его взорванного корпуса и двигательной установки после отступлении частей Красной Армии из Николаева немецкие инженеры. Вероятно, им должен быть авианесущий линейный крейсер типа японского «Хюга» или английского «Корейджэса» с небольшим количеством многоцелевых палубных самолетов ${ }^{83}$.

Бурными темпами в конце 1920-х-30-х годах росло число новых советских танков. 2 июня 1926 года руководством НКО Главному управлению военной промышленностью ВСНХ была предложена трехлетняя программа развития танкостроения. Учитывая российские просторы, слабо развитую дорожную инфраструктуру и сложный рельеф местности советские танкостроители окончательно отказались от тяжелых сухопутных «броненосцов». В 1927 году на вооружение советских автобронетанковых войск был принят легкий танк Т-18, или МС-1 («Малый сопровождения пехоты - первый»), построенный на Сормовском машиностроительном заводе по итальянской лицензии на изготовление легкого танка Фиат L.2/21. Выбор модели был обусловлен тем, что на заводе сохранилась оснастка производственной линии для танков КС-1. Новая бронемашина по существу являлась его модификацией. Ходовая часть танка была изменена танка. Отечественный 45-сильный двигатель конструкции А.А. Микулина был расположен поперек кормы танка, что сокращало габариты машины и улучшало центровку. Пружинная подвеска воспринимала и гасила передаваемые на корпус толчки, а на попарно сблокированных катках впервые в мире устанавливались резиновые бандажи. Все это позволило увеличить скорость движения отечественной версии до $22 \mathrm{~km} / 4 а \mathrm{c}$. В результате вес танка уменьшился до 5,5 тонн и, увеличив толщину лобовой брони, удалось сохранить 37мм пушку, спаренную с курсовым пулеметом. С 1928 по 1931 год этих танков было произведено Сормовским, Харьковским и Ижорским заводами 956 штук. Боевую проверку танки прошли во время вооруженного конфликта на КВЖД в 1929 году, а позже приняли участие в отражении японской 


\section{5 лет Великой Победы}

агрессии в районе озера Хасан осенью 1938 года. Накануне войны 700 этих танков в 1939 году были переданы командованию Киевского и Западного Особых военных округов для вооружения укрепленных районов ${ }^{84}$.

В СССР первыми стали разрабатывать концепцию среднего танка, когда технические требования к этому классу бронированных машин еще не определились. Т-24 стал первым средним серийным танком, так как европейских аналогов не существовало. Отличительная особенность танка заключалась в трехъярусном расположении вооружения, установленного в двух башнях и корпусе. Это позволило одновременно поражать цели, находящиеся в разных направлениях. Он имел удачную компоновочную схему: отделение управления располагалось спереди, боевое - в середине, а моторное - в корме. Таким образом, обеспечивался хороший обзор местности. Экипаж состоял из пяти человек: командир, наводчик, механикводитель и два пулеметчика.

Боевая масса Т-24 составляла 18,5 т. Бронирование танка было противопульным. Толщина брони составляла 20 мм для вертикальных плит. В передней части они были наклонены под сравнительно большими углами к вертикальной плоскости, что дополнительно повышало их защитные свойства. Программа строительства Т-24 предусматривала сдать НКО 300 машин. Однако после изготовления 25 танков производство их прекратили. Проблема состояла не только в конструктивных недостатках. Новая военная доктрина не предусматривала применения средних танков в таком количестве. Все Т-24, в конце концов, оказались в военных училищах, а 2 марта 1938 года по распоряжению Наркома вооружений 22 танка Т-24 были переданы в распоряжение укрепленных районов западных военных округов для создания неподвижных огневых точек ${ }^{85}$.

Отечественные легкие танки непосредственного сопровождения пехоты создавались на базе популярного английского танка Виккерс-Армстронг Mk.IE или, как его еще называли «Виккерс6 тонн», с авиационными моторами воздушного охлаждения. Основными достоинствами «шеститонника» была простота управления, высокая надежность, большой запас хода, достаточный сектор обстрела и дешевизна производства. Финляндия закупила 20 танков для своих национальных вооруженных сил, а правительства Польской республики и Итальянского королевства приобрели лицензии на их производство.

В 1930 году представители Наркомата внешней торговли закупили в Великобритании 15 двухбашенных пулеметных танков и лицензию на их серийное изготовление и последующую модернизацию. Год спустя танк был запущен в массовое производство под литерой Т-26. В нем были опробованы оригинальные конструктивные решения, ставшие позже классическими в отечественном танкостроении. На советском танке устанавливался отечественный автомобильный карбюраторный двигатель водяного охлаждения, в качестве топлива использовался не авиационный, а дешевый советский бензин с низким октановым числом. Его заправка могла производиться на любой машинно-тракторной станции. Мощная ходовая часть танка позволяла на ее базе создавать более совершенные модификации Т26. В годы первой пятилетки бронетанковые части РККА получили 1626 двухбашенных танков Т26 с двумя пулеметами ДТ, а позже с 37-мм пушкой «Гочкис» в левой и пулеметом в правой башне.

С 1933 года начался выпуск танков Т-26А с цилиндрической башней, в которой устанавливалась 45-мм длинноствольная пушка и один курсовой пулемет. Красная Армия получили 2127 «линейных танков» и 3938 радиофицированных, или «радийных» командирских танков Т-26РТ с уменьшенным боезапасом и третьим «зенитным» пулеметом на верху башни. Наконец, Т-26А образца 1939 года имел конические башни с подбашенными коробками, усиленными наклонными броневыми листами, которые были выпущены в количестве 2179 экземпляров. Трофейные 252 легких танков Т-26А были приняты на вооружение финской армии и с успехом применялись в период 1941-1944гг.

Противопульное бронирование - лобовая броня составляла 15 мм - и максимальная скорость на шоссе (35 км/час) оказались к 1938 году недостаточными, но вполне сопоставимыми с характеристиками основного немецкого легкого танка Pz.Kpfw.ll. Всего на вооружении РККА К 1939 году состояло 9 ооо танков Т-26, включая огнеметные, "химические», учебные, двухбашенные и самоходные установки, созданные на их ходовой базе ${ }^{86}$.

Советские быстроходные танки серии БТ строились на основе проекта танка Т-з «Торнадо» американского конструктора У. Кристи. В период Великой депрессии он охотно продал советским торговым представителям за 64 млн долларов лицензию на его производство, проекты его модификаций и всю оснастку своего экспериментального завода.

Внедрение нового танка в производство было поручено Главному конструктору Харьковского тракторного завода А.В. Фирсову, внесшему ряд 
Гребенюк А.В.

существенных изменений в конструкцию «Торнадо». На новом танке БТ-3 установили 37мм длинноствольную французскую танковую пушку «Гочкис», для чего пришлось разработать специальную цилиндрическую башню.

На рокадных и шоссейных дорогах и каменистых пустынях Монголии на восьми обрезиненных катках БТ-2 развивал скорость до 70 км/час, а на гусеницах по пересеченной местности до 50 км/час! Смена и установка гусениц у опытного экипажа занимала всего зо минут. Правда, гусеничные ленты этого танка были крупнозвенчатыми и узкими, и по причине высокой нагрузки на грунт его проходимость в пересеченной местности оставляла желать лучшего. В глубоком снегу БТ-2 часто буксовал, и танк приходилось вытаскивать на твердую поверхность с помощью цепи на лобовой части машины. Да и крышка входного люка вовнутрь машины для механика-водителя находилась на передней лобовой детали танка, что делало танк уязвимым при фронтальной атаке на укрепленные артиллерийские позиции противника и не давало возможности увеличивать толщину лобовой брони. Это требовало от экипажа умения постоянно маневрировать под огнем противника. На испытательных полигонах легкие танки БТ-2, разогнавшись до скорости 50 км/час, с небольших возвышений могли перепрыгивать рвы и водные преграды шириной от 20 до 40 м.

На военном параде 7 ноября 1931 года три новых скоростных харьковских танка и семь Т-26 впервые были показаны на Красной площади членам Политбюро ЦК ВКП(б), иностранным послам и военным атташе. Это стало для официальных зарубежных гостей неприятным сюрпризом, так как мало кто ожидал, что они так быстро были освоены молодой советской тракторной промышленностью ${ }^{87}$.

На БТ-5 и БТ-7 устанавливались отечественные 45-мм длинноствольные бронебойные орудия в сварной башне, новые телескопические прицелы, экранировалась лобовая броня, и ставились дополнительные курсовые пулеметы, а на командирских машинах - радиостанции с поручневой антенной: таких «радийных» танков было выпущено 2117 штук. Антенна была очень заметной приметой для артиллеристов противника, и они концентрировали огонь на этих танках, чтобы вывести из строя командира подразделения. Уже в период советско-финской войны на всех танках устанавливались деревянные имитаторы. Колесные движители использовались при необходимости ускоренной переброски танковых соединений к месту боя. Во время вооруженного конфликта на реке Халхин-Гол в июне 1939 г. к горе Баин-Цаган была неожиданно для японцев выдвинута 11я танковая бригада, которая двигалась со средней скоростью 55 км/час.

В 1939 году на всех легких танках установили новую 45-мм пушку 19К с увеличенным числом нарезов в стволе, что повышало начальную скорость снаряда и его бронебойные качества. Но танкисты не хотели изучать новые прицелы и пользовались старыми приборами, что снижало точность стрельбы.

На последних модификациях БТ-7М вместо 45-мм пушки устанавливалось 76-мм танковое орудие Ф-22. Пожароопасные лицензионные авиационные американские двигатели М-5Т заменялись авиационными моторами водяного охлаждения М-17Т на БТ-5 и БТ-7, а затем на БТ-7М - мощными отечественными танковыми дизелями В-2. Максимальная скорость возросла, ходовые характеристики в принципе не изменились, а попадание снаряда в моторный отсек теперь редко приводили к немедленному возгоранию топливных баков. Всего было выпущено 715 БТ-7М с дизельной двигательной установкой и усиленной лобовой броней[88]. Всего в тридцатые годы было выпущено 950 танков БТ-2, 1884 танков БТ-5, 4 6оо танков БТ-7 и 2115 БТ-7М, то есть 9565 «линейных машин».

В современной литературе сложилось предвзятое представление о советских легких танках как устаревших, что в лексиконе «хрущевской оттепели» означало отсталые и небоеспособные порождения сталинизма. Однако по своим тактико-техническим характеристикам и вооружению БТ-2, БТ5 и БТ-7 превосходили германские танки Pz.Kpfw..$^{89}$ и Pz.Kpfw.II90, итальянские Фиат L.10/40 и польские 7TR, не говоря уже о финских «виккерсах».

Тяжелые и средние танки атаковали сильные укрепленные вражеские позиции в лоб, так как благодаря неповторимым конструктивным особенностям их ходовой части могли преодолевать неглубокие танковые рвы и траншеи, а их мощной лобовой броне были не страшны малокалиберные снаряды противотанковых орудий и бронебойных ружей вероятного противника. Все советские танки этих классов имели приемо-передающие радиостанции.

Сталинградским, Кировским иЧелябинским тракторными заводами было выпущено 411 средних танков трехбашенных Т-28 в пяти модификациях. В 1939 году короткоствольная 76-мм пушка КТ-28 на большинстве этих машин заменялась длинноствольным орудием Л-11 с высокой начальной скоростью снаряда. Стандартный боекомплект Т-28 составлял 70 снарядов и 7938 патронов к четырем пулеметам. 


\section{5 лет Великой Победы}

Благодаря продуманному размещению бортового оружия эти танки могли вести круговой о6стрел. В 1940 году было выпущено 13 танков с конической башней, а броневая защита серийных танков прежних выпусков усиливалась за счет установки дополнительных бронированных экранов на корпусе и башнях. Их называли Т-28Э. Танк обладал прекрасной проходимостью и, благодаря плавности хода, изумительной точностью стрельбы. Он легко преодолевал стандартные противотанковые рвы. Захваченные в ходе советско-финляндской войны Т-28, финские танкисты применяли в 1941-1944 гг. Два таких танка приобрела Турция для изучения конструкции, откуда они попали в Берлин. Ходовая часть этого танка впоследствии была воспроизведена в лучшем немецком танке второй мировой войны Pz.Kpfw.V «Пантера» ${ }^{91}$.

На Харьковском тракторном заводе был построен 61 пятибашенный тяжелый танкТ-35, вскоре снятый с производства. Боезапас Т-35 составлял 316 снарядов к трем орудиям и 10000 патронов к шести пулеметам ${ }^{92}$.

Большое внимание руководство Управления механизации и моторизации РККА уделяло танкеткам или «малым танкам». Это объяснялось двумя соображениями. Во-первых, особенности пересеченного ландшафта и значительные расстояния настоятельно требовали организации устойчивой связи между соединениями, что в силу неразвитой телефонной сети и радиоэлектронной промышленности оставалось острой проблемой. Вовторых, для обеспечения огневой поддержки кавалерийских и стрелковых подразделений на марше или при форсировании водных преград нужны были экономичные быстроходные бронемашины.

В 1928 году в Англии Главное управление военной промышленности BCHX приобрело лицензию на производство танкетки Карден-Ллойд Mk.VI. Coветский вариант Т-27 не был точной копией своего аналога. Были увеличены размеры, установлен более мощный четырехцилиндровый двигатель советского серийного грузового автомобиля ГАЗАА. Корпус Т-27 состоял из катаных броневых листов толщиной 6-10 мм, которые соединялись заклепками и сваркой. В качестве вооружения был предусмотрен пулемет ДТ. Для увеличения внутреннего объема танкетки двигатель и трансмиссия располагались по бортам корпуса.

Хорошая подвижность и достаточная для того времени защищенность позволяли использовать танкетки в составе кавалерийских частей. В 1935 году на Киевских военных маневрах была продемонстрирована возможность транспортировки Т-27 на внешней подвеске бомбардировщика ТБ-з. После посадки и остановки самолетов танкетки сбрасывались с метровой высоты и тут же уходили выполнять задание. Всего с 1931 по 1933 год было выпущено и передано в части Красной Армии около 3300 танкеток Т-27. Около двух тысяч этих танкеток участвовали в первых боях Великой Отечественной войны.

Плавающий танк Т-37А, созданный на ходовой базе английской танкетки, оказался сложным в эксплуатации из-за использования отечественных агрегатов: они часто выходили из строя под воздействием воды. Однако вместо того, чтобы снять его с производства, из Главного автобронетанкового управления поступило распоряжение модернизировать танк. «В то время свято верили, писал известный танкостроитель Н.А. Астров, - что малый, именовавшийся разведывательным, танк со слабым вооружением (один пулемет калибра 7,62 мм), с противопульным бронированием, зато плавающий, - совершенно необходимый, важный вид бронетанкового вооружения Красной Армии. Модернизированный нами танк с индексом Т-38 получил вместо дифференциального механизма поворота бортовые фрикционные с ленточными тормозами в корпусе, иной привод гребного винта, позволявший включать его без остановки. Перекомпоновав машину, сократили ее высоту, увеличили опорную базу и понизили центр тяжести. Благодаря этому... возросла эффективность стрельбы с хода. Повышение боевых свойств оказалось довольно заметным, и Т-з8 после испытаний и, главное, обязательного показа И.В. Сталину был принят к производству. В 19361937 гг. его выпускали на московском заводе, и небольшое количество Т-з8 участвовало в Великой Отечественной войне, в ее первый период»93.

Российские конструкторы бронетанковой техники явились новаторами в области создания самоходных артиллерийских установок. В 1934 году на усиленных шасси Т-26 были созданы первые 42 отечественных серийных самоходных артиллерийских установки Т-26А-4 с 76-мм зенитной пушкой в полностью закрытой сварной башне. Во встречном танковом бою «самоходки» оказались попросту бесценным оружием, расстреливая немецкие танки с дальней дистанции. В 1935 году ходовая часть Т-26 была использована для самоходной установки АТ-1 с 76-мм полковым орудием Ф-22. На ходовой базе БТ-7 были созданы 156 гусеничных артиллерийских установок БТ-7А с длинноствольной танковой 76-мм пушкой Л-10. Их применяли, как и танки БТ-7М. В 1938 году появился новый бесперспективный плавающий танкТ40 и «малый танк» Т-40С с противопульной броней 
Гребенюк А.В.

и крупнокалиберным пулеметом, впоследствии на нескольких сотнях машин замененным 20-мм скорострельной авиационной автоматической пушкой с боекомплектом 175 бронебойных снарядов. Всего армейским подразделениям было сдано 709 этих танков ${ }^{94}$.

На Ленинградском заводе опытного машиностроения № 174 в конце 1939 года был спроектирован принципиально новый легкий танк Т-50. Катаные броневые листы, установленные с рациональным наклоном, имели толщину 45 мм. В граненой сварной башне была установлена 45-мм скорострельная пушка, спаренная с пулеметом ДТ. Танк долго испытывался, и был запущен в малую серию по причине небольшого количества готовых дизельных двигателей В-4. До снятия с производства в 1942 году было выпущено всего 250 танков $^{95}$.

Молодые инженеры конструкторского бюро Харьковского тракторного завода М.И. Кошкин, Н.А. Кучеренко, А.А. Морозов и М.И. Таршинов разработали проект колесно-гусеничного танка А20, в котором был воплощен ряд найденных ими интересных инженерных решений. В частности к ним следует отнести сварной корпус оригинальной формы, когда большие углы наклона броневых листов заставляли снаряды неприятельской артиллерии рикошетировать, что обеспечивало высокую снарядостойкость танка, и коническую сварную башню. Несколько позже появился прототип колесно-гусеничного танка А-зо с пятью парами ведущих колес, усиленным артиллерийским вооружением, широкими траками и мощной броневой защитой. При эксплуатационных испытаниях выяснилось, что при возросшей массе машины ее применение в колесном варианте теряет всякий смысл. На Харьковском тракторном заводе начались инициативные работы по созданию чисто гусеничного танка А-32 (Т-32). Его основные узлы были впоследствии использованы в легендарном советском среднем танке второй мировой войны Т-34 ${ }^{96}$. «Патриоты» комбинированного танкового движителя оказались в большинстве, тем более что на их стороне был и Герой Советского Союза комбриг Д.Г. Павлов, недавно возвратившийся из Испании, и идея постройки гусеничного танка была отвергнута ${ }^{97}$.

На основе тяжелого танка Т-35 начался выпуск малой серии из 32 самоходных артиллерийских установок СУ-14 Бр-2 с бронированной закрытой рубкой и оснащенной 152-мм пушкой. На эксплуатационных испытаниях выяснилось, что из-за значительной массы - 65 т - ее боекомплект, проходимость, скорость и запас хода не удовлетворяли требованиям Главного автобронетанкового управления. Вся экспериментальная серия этих самоходных артиллерийских установок поступила в механизированные подразделения Киевского военного округа, где секретные «тяжелые танки» приняли участие в первых боях Великой Отечественной войны ${ }^{98}$.

Наряду с механизированными корпусами стали комплектоваться моторизованные броневые бригады в составе отечественных средних 6ронеавтомобилей БА-10. Они создавались на базе шасси стандартного грузового трехосного автомобиля ГАЗ-6. Броневики оснащались 45-мм длинноствольной танковой пушкой и 2 курсовыми пулеметами. Они развивал максимальную скорость 87 км/час на шоссе и 50 км/час на бездорожье. Его лобовая броня была толще брони «линейного» танка БТ-5. Он применялся на сильно пересеченной местности, где легкие танки с их узкими траками часто застревали, а мощные авиационные двигатели часто перегревались и выходили из строя. По своим скоростным характеристикам, мощности мотора и ширине колеи бронеавтомобили БА-1о уступали зарубежным аналогам, но их отличала неприхотливость в эксплуатации во фронтовой обстановке и, благодаря широкой колее и большему диаметру колес, неплохая проходимость. Их карбюраторные двигатели были просты и надежны, а ремонтные качества - сравнительно высокими.

Этими машинами комплектовались отдельные моторизованные броневые бригады по 154 «колесных танка» в каждой. 7-я усиленная мотобронебригада под командованием полковника А.Л. Лесового участвовала в военном конфликте на Халхин-Голе. Всего было построено 4 о0о броневиков БА-10 разнообразных модификаций, включая плавающие бронеавтомобили ПБ-4. Одновременно для ведения разведки строились на шасси легкового автомобиля ГАЗ М-1 легкие броневики БА-20 с одним пулеметом 99.

Осенью 1932 года на базе 11-й стрелковой дивизии в Ленинградском военном округе был сформирован 11-й механизированный корпус, а на базе 45-й стрелковой дивизии в Украинском военном округе - 45-й механизированный корпус. В их состав входили танковая бригада танков Т-26 и три батальона, укомплектованных быстроходными танками БТ-2. Механизированный корпус имел по штатному расписанию 463 танка, 200 средних бронеавтомобилей и 60 артиллерийских орудий различных калибров.

С 12 по 15 сентября 1935 года на Киевских маневрах впервые в действии были продемонстрированы первые советские механизированные корпуса, которые являлись принципиально новой 


\section{5 лет Великой Победы}

формой организации автобронетанковых войск. Силами пехоты и тяжелых танков подразделения «красных» прорвали оборону «синих», после чего под прикрытием дымовой завесы в их расположение ворвались оба механизированных корпуса, укомплектованных скоростными и малыми танками. Их с воздуха поддерживали легкие штурмовики.

Успеху «красных» способствовало успешное десантирование 1200 парашютистов, которые создали круговую оборону для приема на подготовленных ими аэродромах тяжелых четырехмоторных военно-транспортных самолетов ТБ-з с тяжелым наступательным вооружением и боеприпасами. Оно включало разведывательные танкетки и легкие плавающие танки Т-37. После их приземления состав десантников пополнился еще 2500 бойцами. Американский публицист Г. Россинский позже писал: «Сочетание парашютных десантов, захватывающих аэродромы, с посадочными десантами, использующими их, является страницей, вырванной из книги о Красной Армии, которая первая продемонстрировала эти методы в широких масштабах на маневрах 1935 года. В то время германские специалисты были настроены весьма скептически, считая, что этот новый вид оружия имеет шансы на успех лишь в малонаселенных районах.... К концу 1938 года в германской армии был только один батальон парашютистов; к весне 1939 года этот батальон был расширен до размеров полка» ${ }^{100}$.

В Полевом уставе 1936 года впервые были конкретно определены тактические задачи и структура воздушно-десантных батальонов. Они преобразовывались в воздушно-десантные бригады, каждая в количестве 4500 кадровых военнослужащих - парашютистов и бойцов «посадочного десанта», - 10 легких танков Т-37, 18 противотанковых орудий и бронеавтомобили БА64. Полностью укомплектованными к началу гитлеровского вторжения оказались 5-я Одесская, 6я Керченская, 212-я Киевская и 214-я Дальневосточная десантные бригады.

Проблема репрессий в РККА и ВМФ остается одной из самых обсуждаемых в литературе тем предвоенной истории СССР. Оставляя в стороне вопрос о политических мотивах «кадровой чистки», ограничимся цифрами уволенных командиров и политических работников, приведенныхв отчете заместителя наркома обороны СССР Е.А. Щаденко.

ОТЧЕТ ЗАМЕСТИТЕЛЯ НАРКОМА ОБОРОНЫ СССР НАЧАЛЬНИКА УПРАВЛЕНИЯ ПО КОМАНДНОМУ И НАЧАЛЬСТВУЮЩЕМУ СОСТАВУ РККА Е.А. ЩАДЕНКО (От апреЛЯ 1940 г.) О КОЛИЧЕСТВЕ АРЕСТОВАННЫХ И УВОЛЕННЫХ В 1937-1939 ГГ. КОМАНДИРОВ КРАСНОЙ АРМИИ

ОТЧЕТ о работе Управления по начальствующему составу РККА за 1939 г.

(...) Очистка армии и пересмотр уволенных (без ВВС)

(...) В 1935 г. уволено 6198 чел. или 4,9\% к списочной численности

В 1936 г. уволено 5677 чел. или 4,2\% к списочной численности

В 1937 г. уволено 18658 чел. или 13,1\% к списочной численности (из них политсостава - 2194 чел.). Из общего числа уволенных в 1937 г.:

\begin{tabular}{|l|c|c|c|}
\hline \multicolumn{1}{|c|}{ мотивы увольнения } & $\begin{array}{c}\text { всего увол. в } \\
1937 \text { г. }\end{array}$ & $\begin{array}{c}\text { Из числа увол. восстанов- } \\
\text { лено в 1938-39 гг. }\end{array}$ & $\begin{array}{c}\text { Фактич. осталось } \\
\text { уволенных }\end{array}$ \\
\hline а) арестованы & 4474 & 206 & 4268 \\
\hline $\begin{array}{l}\text { б) уволены во испол. решения } \\
\text { ЦК ВКП(б) № П47/102 от 29.3.37. } \\
\text { искл. из ВКП(6) за связь с заго- } \\
\text { ворщиками) }\end{array}$ & 11104 & 4338 & 6766 \\
\hline $\begin{array}{l}\text { В) уволены по политико- мо- } \\
\text { ральным причинам (пьяницы, } \\
\text { мор. разлож., расхитители нар. } \\
\text { достоян.) }\end{array}$ & 1139 & 109 & 1030 \\
\hline $\begin{array}{l}\text { г) исключ. за смертью, по инва- } \\
\text { лидности и болезни }\end{array}$ & 1941 & 8 & 1933 \\
\hline ВСЕГО: & 18658 & 4661 & 13997 \\
\hline \%\% К списоч. численности & $13,1 \%$ & & $9,7 \%$ \\
\hline
\end{tabular}


Гребенюк А.В.

\begin{tabular}{|l|c|c|c|}
\hline \multicolumn{1}{|c|}{ мотивы увольнения } & $\begin{array}{c}\text { всего увол. } \\
\text { в 1938 г. }\end{array}$ & $\begin{array}{c}\text { Из числа увол. восста- } \\
\text { новлено в 1939 гг. }\end{array}$ & $\begin{array}{c}\text { Фактич. осталось } \\
\text { уволенных }\end{array}$ \\
\hline а) арестованы & 5032 & 1225 & 3807 \\
\hline $\begin{array}{l}\text { 6) уволены во испол. реше- } \\
\text { ния ЦКК ВКП(6) № П47/102 от } \\
\text { 29.3.37. (искл. из ВКП(6) за } \\
\text { связь с заговорщиками) }\end{array}$ & 3580 & 2864 & 716 \\
\hline $\begin{array}{l}\text { в) уволены по дирек. НКО от } \\
\text { 24.6.38. №2оо/ш (поляки, нем- } \\
\text { цы, латыши, литовцы, фины, } \\
\text { эстонцы, корейцы идр., урож. } \\
\text { заграницы и связанные с ней }\end{array}$ & 4138 & 1919 & 2 \\
\hline $\begin{array}{l}\text { г) уволены во испол. прик. } \\
\text { НКО №о219-19з8 (пьяницы, } \\
\text { мор. разлож., расхитители } \\
\text { нар. достоян.) }\end{array}$ & 2671 & 321 & 2350 \\
\hline $\begin{array}{l}\text { д) исключ. за смертью, по ин- } \\
\text { валидности и болезни }\end{array}$ & 941 & 4 & 937 \\
\hline ВСЕГО: & 16362 & 6333 & 10029 \\
\hline \%\% к списоч. численности & $9,2 \%$ & & $5,6 \%$ \\
\hline
\end{tabular}

В 1939 г. уволено 1878 чел. или 0,7 к списочной численности (из них политсостава - 477 чел.). Из о6щего числа уволенных в 1939 г.:

\begin{tabular}{|l|c|c|c|}
\hline \multicolumn{1}{|c|}{ мотивы увольнения } & $\begin{array}{c}\text { всего увол. } \\
\text { в 1939 г. }\end{array}$ & $\begin{array}{c}\text { Из числа увол. восста- } \\
\text { новлено }\end{array}$ & $\begin{array}{c}\text { Фактич. осталось } \\
\text { уволенных }\end{array}$ \\
\hline а) арестованы & 73 & 26 & 47 \\
\hline $\begin{array}{l}\text { 6) уволены во испол. реше- } \\
\text { ния ЦК ВКП(6) № П47/102 от } \\
\text { 29.3.37. (искл. из ВКП(6) за } \\
\text { связь с заговорщиками) }\end{array}$ & 284 & 126 & 158 \\
\hline $\begin{array}{l}\text { в) уволены во испол. прик. } \\
\text { НКО №о219-19з8 (пьяницы, } \\
\text { мор. разлож., расхитители } \\
\text { нар. достоян.) }\end{array}$ & 238 & 23 & 215 \\
\hline $\begin{array}{l}\text { г) исключ. за смертью, по ин- } \\
\text { валидности и болезни }\end{array}$ & 1283 & 9 & 1274 \\
\hline ВСЕГО: & 1878 & 184 & 1694 \\
\hline \%\% к списоч. численности & $0,7 \%$ & $0,6 \%$ & \\
\hline
\end{tabular}

(...) В общем числе уволенных как за 1936-37 гг., так и за 1938-1939 гг. было большое количество арестовано и уволено несправедливо. Поэтому много поступало жалоб в Наркомат Обороны, в ЦК ВКП(6) и на имя тов. Сталина. Мною в августе 1938 г. была создана специальная комиссия для разбора жалоб уволенных командиров, которая тщательно проверяла материалы уволенных путем личного вывоза их, выезда на места работников Управления, запросов парторганизаций, отдельных коммунистов и командиров знающих уволенных, через органы НКВД и т.д.

Комиссией было рассмотрено около зо тыс. жалоб, ходатайств и заявлений... Всего восстановлено 11178 чел. Эти восстановленные были уволены: приказами НКО - 4030 чел.; приказами округов -7148 чел.... Е. ЩАДЕНКО»101.

Необходимо отметить, что маховик репрессий начал раскручиваться после неутешительных известий из Испании и Китая, куда были направлены советские военные советники, добровольцы и новейшая отечественная техника. Этому хронологическому совпадению исследователи никогда не придавали значения. Советские самолеты в Испании и Китае в это время стали нести ощутимые 


\section{5 лет Великой Победы}

потери от новых немецких и японских самолетов, а работа военных советников при организации боевой деятельности авиационных подразделений велась согласно ошибочным боевым наставлениям. Все попытки организовать взаимодействие маневренных истребителей вели лишь к неоправданным потерям ${ }^{102}$. Анализ военных повреждений, полученных танками БТ-5 в период боев в Испании, показал, что они, обладая хорошей проходимостью, мощным вооружением и другими значительными преимуществами над пулеметными итало-немецкими танками, имели несовершенную механическую комбинацию колесного и гусеничного движителя. Управление ими в горных условиях оказалось чрезвычайно сложным делом, и было доступно только опытным образованным командирам. Будучи сравнительно высокими, узкими и недостаточно устойчивыми, советские танки не могли развивать большую скорость без угрозы опрокинуться даже на небольших поворотах ${ }^{103}$

Представляется, что И.В. Сталин сделал три верных вывода о причинах начавшего отставания советской военной техники. Во-первых, и в Испании, и в Китае стратегическая инициатива всегда принадлежала противникам Народного Фронта и Гоминдана, что заставляло республиканскую и китайскую армии придерживаться в основном оборонительной тактики. Во-вторых, они уступали противнику в боевой подготовке личного состава и количестве военной техники. В-третьих, стремление добиться количественного превосходства боевой советской техники над тяжелыми вооружениями вероятного противника без радикального качественного улучшения всех ее тактико-технических параметров являлось опасной иллюзией. И одновременно Сталин впал в другую крайность, забыв, что опыт локальных вооруженных конфликтов нельзя распространять на стратегию глобальной войны.

За техническое состояние РККА отвечал непосредственно заместитель наркома обороны по вооружению маршал М.Н. Тухачевский ${ }^{104}$. Он же по должности нес ответственность за подготовку личного состава. Хотя очевидной системы в череде арестов не наблюдается, в связи с «судебным процессом военно-троцкистского центра» были арестованы начальники всех управлений, ведавшими учебными заведениями всех родов войск и службы технического и материального обеспечения РККА.

Все конструкторские бюро, занимавшиеся разработкой новых образцов авиационной техники, так или иначе, были связаны с деятельностью М.Н. Тухачевского. Были арестованы авиаконструкторы
А.Н. Туполев, П.О. Сухой, В.М. Петляков, Р.Л. Бартини, А.И. Путилов, В.М. Мясищев, К.А. Калинин, Л.М. Томашевич, Л.Л. Кербер, И.Г. Нейман и создатель ракетной техники С.П. Королев. Они оказались в «Специальном техническом бюро» КБ-28 НКВД СССР тюремного типа в Москве ${ }^{105}$. Инженеры-кораблестроители А.Н. Асафов, С.А. Базилевский, Б.М. Малинин, Э.Э. Крюгер, К.И. Руберовский и многие другие были помещены в «Особое техническое бюро» при КБ-зо НКВД СССР в Ленинграде ${ }^{106}$. Изобретатель систем сбрасывания тяжелых вооружений на парашютах для воздушно-десантных подразделений комбриг П.И. Гроховский и инженер В.С. Вахмистров, которому принадлежали варианты составных самолетов «Звено» надолго оказались в бараках ГУЛага.

Репрессиям подверглось и высшее руководство военно-морского флота. Были арестованы заместитель наркома обороны по морским силам флагман флота 1-го ранга А.В. Орлов, начальник политотдела ВМФ армейский комиссар 1-го ранга П.А. Смирнов, заместитель наркома тяжелой промышленности СССР по судостроению флагман флота 1-го ранга Р.А. Муклевич, начальник Военно-морской академии флагман флота 2-го ранга К.И. Душенов и все командующие флотами и флотилиями. Были репрессированы начальник Управления кораблестроения ВМФ флагман флота 2-го ранга Н.И. Власьев и начальник НТК капитан 1-го ранга Н.П. Игнатьев. Был создан Народный комиссариат ВМФ, который возглавил флагман флота 1-го ранга М.П. Фриновский. Он был самой крупной креатурой всесильного Генерального комиссара госбезопасности Н.И. Ежова. До своего назначения Фриновский возглавлял Главное Управление пограничных войск НКВД. Естественно, в тактике применения боевых кораблей и организации береговой обороны он совершенно не разбирался, но был арестован не по этой причине, а за личные связи с отстраненным от должности «врагом народа» Н.И. Ежовым. До ареста Н.И. Ежова в марте 1939 года обязанности наркома РККФ исполнял флагман флота 2-го ранга Н.Г. Кузнецов, недавно возвратившийся из республиканской Испании, где был военным советником ${ }^{107}$.

Последовавшие за испанскими событиями первоначальные поражения ОКДВА в районе озера Хасан в 1938 году, привели к аресту маршала В.К. Блюхера. Вслед за ним исчезли в застенках следственной тюрьмы НКВД в Хабаровске начальник артиллерии ОКДВА комбриг Д.Д. Муев, военный атташе в Китае комкор А.И. Геккер и военный атташе в Японии комкор А.И. Кукк. За короткое время были арестованы практически все 
Гребенюк А.В.

высшие авиационные командиры, включая начальника Главного управления ВВС РККА командарма 2-го ранга Я.И. Алксниса, начальника Штаба ВВС комкора В.В. Хрипина, начальника Политического управления ВВС армейского комиссара 1-го ранга Э.С. Панцержанского, начальника Высшей парашютной школы комдива Я.Д. Мошковского, всех командующих ВВС военных округов и военно-морских атташе во Франции, Японии и Китаe $^{108}$.

Молодые инженеры, как правило, не имели ни достаточного опыта конструирования, ни определенных организаторских навыков. Наркоматами им всем предписывалось только совершенствовать серийные образцы боевой техники и ни в коем случае не срывать плановых заданий партии и правительства. Так, увеличение максимальной скорости самолетов достигалось за счет уменьшения прочности планера, высотности и дальности, повышение броневой защиты танков и увеличения калибра башенных орудий вело к уменьшению боекомплекта и маневренности, а усиление вооружения боевых кораблей происходило путем сокращения огневых средств противовоздушной обороны.

На авиационных заводах развернулось массовое производство морально устаревших истребителей-бипланов И-153 «Чайка» с пулеметным вооружением, предназначенных для замены И16. «И-153 был единственным в Советском Союзе серийным бипланом с убирающимися шасси и лучшим из когда-либо созданных истребителей-бипланов. Но это был лишь последний, лучший представитель отжившего класса самолетов. «Он утратил главное качество истребителя - возможность всегда навязать бой любому самолету врага и выйти из боя, когда это необходимо: он имел ограниченную скорость», - писал выдающийся советский авиаконструктор А.С. Яковлев ${ }^{109}$.

Отечественная ствольная артиллерия являлась одной из лучших в мире. Но и здесь И.В. Сталин предпочитал лично определять пути ее дальнейшего совершенствования, считая, что универсальная107-мм пушка должна полностью заменить 76-мм полковые и 45-мм противотанковые орудия. Теоретически ее можно использовать и в качестве морской зенитки, и в качестве орудия артиллерии Резерва Главного Командования, и в качестве танковой пушки, поскольку ее снаряд действительно пробивал лобовую танковую броню любой толщины и броневые пояса надводных кораблей, вплоть до линкоров. Противник такого решения нарком вооружений Б.Л. Ванников был арестован. Экспериментальное 107-мм орудие конструкции В.Г. Грабина было испытано только в начале 1941 года. Из них удалось к началу войны сформировать только один артиллерийский пол $\mathrm{K}^{110}$.

В то же время, производство 45-мм противотанковых и 76-мм дивизионных орудий и боеприпасов к ним было прекращено. До принятия на вооружение нового орудия приказывалось экономить боеприпасы. Противотанковым дивизионам на учениях разрешалось производить не более пяти выстрелов боевыми снарядами. Поскольку 76-мм пушки устанавливались на новые танки Т-34 и КВ-1, у танкистов также возникли проблемы со снарядами. Теперь на каждое 76-мм орудие моторизованной дивизии приходилось по штату по 12 снарядов в день, на 76-мм дивизионное орудие образца 1938/39 года - по 20 снарядов, на 76-мм пушку тяжелого танка КВ-1 - по 85 снарядов и на среднем танке Т-34-по 13 снарядов. И, несмотря на полное восстановление их производства по распоряжению Сталина в 1941 году, в начале Великой Отечественной войны в артиллерийских батареях, танковых полках, на кораблях и бронекатерах катастрофически не хватало снарядов $^{111}$.

К концу 1930-х годов обстановка в Европе продолжала накаляться. Германия усиленно перевооружала свою армию, что не могло не вызывать беспокойства у ведущих западноевропейских держав, СССР и США. Версальская система в стратегическом отношении представляла собой достаточно гармоничную систему. Германия как потенциальный агрессор была полностью окружена небольшими государствами с непропорционально сильными сухопутными армиями, которые постоянно координировали свои оборонительные планы с Генеральным штабом Франции. Эта система позволяла немедленно реагировать на любые военные акции Германии. Общая граница с дружественной фюреру Италией отсутствовала. Образно говоря, в содействии Советского Союза для сохранения сложившегося миропорядка Лига Наций не нуждалась. Озабоченность Великобритании своими колониальными проблемами заставляла правящий кабинет Соединенного Королевства навязывать Лиге Наций политику «умиротворения» Германии, которая являлась диаметрально противоположной не только советской концепции, но существовавшей общеевропейской системе обеспечения безопасности. В имперских масштабах английских интересов территориальные споры внутри континентальной Европы выглядели незначительными инцидентами. Д. Чемберлен вынудил в апреле 1938 года Лигу Наций признать легитимность «аншлюса» Австрии. Италия и Германия 


\section{5 лет Великой Победы}

получили единую транспортную инфраструктуру и смогли маневрировать своими вооруженными силами и резервами. Мюнхенское соглашение уничтожило Чехословакию. Вермахт получил все тяжелые чешские вооружения, в том числе 598 современных танков и 1514 боеспособных военных самолетов всех классов. В распоряжении военной промышленности Германии оказались крупнейшие промышленные предприятия Центральной Европы: заводы «ЧКД», «Татра», «Шкода», «Авиа» и «Аэро». На них немецкими специалистами было организовано массовое производство современных вооружений, включая танки, самолеты и артиллерийские орудия. Так, до 1943 года для вермахта было произведено 1400 танков LT.38, по немецкой классификации Pz.Kpfw.38(t) ${ }^{112}$. Союзником Германии в разделеЧехословакии стала Польша, которая, таким образом, de facto продемонстрировала готовность проводить независимую от Парижа внешнюю политику.

Французская промышленность в течение 19181938 годов сумела выпустить 280 новых легких танков Рено D.1 и AMR.33, 500 средних танков Соммa S.35 и три тяжелых танка. Французское правительство рассчитывало на чехословацкие танковые заводы с их огромными производственными мощностями. Теперь ему пришлось срочно налаживать строительство бронированных машин на небольших автомобильных и тракторных предприятиях. Прежняя Версальская система усилиями Великобритании перестала существовать.

Гитлер прекрасно ориентировался в стиле мышления своих противников. План завоевания Европы в Министерстве иностранных дел «третьего рейха» и Генеральном штабе вермахта был просчитан по указаниям фюрера с учетом всех органических пороков доктрины «взаимодополняющей общеевропейской обороны». Тем не менее, возможность совместных действий Англии, Франции и СССР coхранялась даже после Мюнхена. В апреле 1939 года в Лондоне начались предварительные переговоры о заключении военного союза между представителями Великобритании, Франции и Советского Союза. 11 августа 1939 года переговоры продолжились в Москве. Английскую военную миссию возглавлял личный советник короля Георга VI адмирал Р. Дракс, французскую - заместитель начальника Генерального штаба дивизионный генерал П. Думенк. Советский Союз на переговорах представлял нарком обороны Маршал Советского Союза К.Е. Ворошилов. Маршал Б.М. Шапошников изложил конкретный план военных действий против агрессоров. Советский Союз готов был развернуть в случае войны 120 стрелковых и 16 кавалерийских дивизий, выставить 5000 тяжелых орудий на механической тяге, 10 ооо танков всех типов и 5 ооо боевых самолетов. Французское военное командование планировало сдерживать противника на прекрасно оборудованной в инженерном и артиллерийском отношении «линии Мажино», выставив 100 регулярных пехотных дивизий, 3800 танков, 3000 артиллерийских орудий на механической тяге и 2 ооо боевых самолетов «первой линии». Вице-адмирал Дракс сообщил, что в случае войны Великобритания способна предварительно перевезти на континент 6 пехотных дивизий, а в случае необходимости сформировать еще 9 дополнительных дивизий, оставив в Англии 16 резервных дивизий. Воздушную поддержку английского экспедиционного корпуса должны были обеспечивать 3 ооо военных самолетов различных типов, большей частью истребителей. У.Черчилль уточнил в своих мемуарах, что во французской армии в действительности имелось 2300 боеспособных танков и 1600 истребителей и бомбардировщиков «первой линии», а у англичан - 328 пехотных танков и 600 боевых самолетов устаревших конструкций ${ }^{113}$.

Переговоры продемонстрировали полную противоположность взглядов представителей трех держав на стратегию и тактику ведения войны, тем более что Польша категорически отказалась в них участвовать. Видя такое развитие событий, Москва решила не рисковать и пойти на сближение с Германией.

23 августа 1939 года по инициативе Гитлера в Москве был подписан советско-германский Договор о ненападении, известный как «пакт Молотова - Риббентропа». 1 сентября 1939 года началась германская агрессия против Польши. В тот же день внеочередная сессия Верховного Совета СССР приняла «Закон о всеобщей воинской обязанности», завершивший переход к кадровой системе комплектования и организации РККА. Это свидетельствует о том, что И.В. Сталин никогда всерьез не верил в искренность германских мирных намерений. 17 сентября 1939 года, когда польское правительство эмигрировало в Румынию, начался «Освободительный поход» Красной Армии на Западную Украину и Западную Белоруссию. В нем приняли участие 15-й и 25-й механизированные корпуса под командованием С.М. Кривошеина и И.О. Яркина, наступавшие на Брест и на Львов.

Комбриг И.О. Яркин в первый же день утерял управление своим корпусом. Спустя два дня из строя из-за перегрева двигателей, поломок трансмиссий, неритмичного подвоза горюче-смазочных материалов и элементарной неопытности 
командиров и механиков, призванных из запаса, большинство танков осталось на обочинах и кюветов дорог под охраной своих экипажей! Командование 25-го механизированного корпуса прибыло на встречу с германскими офицерами на мобилизованных колхозных лошадях. Стоит ли этому удивляться, когда на техническую подготовку советских танкистов отводилось всего 50 учебных часов. Сам комбриг только в 1935 году получил звание лейтенанта и должность командира роты, а после возвращения из Испании сразу получил генеральские петлицы ${ }^{114}$.

Комбриг С.М. Кривошеин привел в Брест 17 танков БТ-7 и 10 плавающих танков Т-з8. Вот как описал этот эпизод генерал-полковник Л.М. Сандалов: «На брестском направлении указанная линия демаркации была нарушена войсками немецкой группы армий "Север", во главе которой стоял генерал-фельдмаршал Т. фон Бок. Моторизированный корпус этой группы переправился через Западный Буг, захватил значительный район вокруг Бреста и стал распространяться на восток от него. Командующий 4-й армией комдив Чуйков <...> приказал авангардной танковой группе комбрига С.М. Кривошеина занять Брест и заставить немецкие войска отойти за Буг. В Бресте состоялась встреча Кривошеина с Гудерианом при участии сотрудника Наркоминдела» ${ }^{115}$. Разумеется, командарм своей властью никогда не мог отдать подобного приказа, не получив прямого одобрения из Кремля.

По предложению Кривошеина на привокзальной площади города был организован военный парад. Впереди двигались покидавшие Брест немецкие пехота и танки, а вслед за ними шли боевые краснозвездные машины с расчехленными орудиями. После марша советские танки вышли на железнодорожные пути и направили пушки на паровозы, которые должны были вывести имущество, реквизированное у еврейского населения, и музейные ценности. В результате воинские части вермахта покинули разграбленный город налегке.

Первый лорд Адмиралтейства Соединенного Королевства У. Черчилль в своем выступлении в Палате общин признал: «То, что русские армии должны были встать на этой линии [Керзона], было совершенно необходимо для безопасности России против нацистской угрозы. Как бы то ни было, эта линия существует, и создан Восточный фронт, который нацистская Германия не осмелится атаковать. Когда господин Риббентроп на прошлой неделе был вызван в Москву, ему пришлось узнать и принять тот факт, что осуществление нацистских планов по отношению к прибалтийским странам и Украине должно быть окончательно остановлено» ${ }^{116}$

Непростая обстановка, связанная с перемещением войск к новой государственной границе, сложилась в Западной Белоруссии и Украине, или в прежней «Польше "Б"». Казарменный фонд бывшей польской армии оказался ничтожно мал, а построенные накануне первой мировой войны фортификационные сооружения Осовца, Ивангорода, Нарвы, Перемышля, Бреста и оборонительные форты Львова пришли в упадок. Военного значения они не имели, и туда переводились госпитали и оружейные склады польской армии.

Железнодорожная сеть осталась такой же, как накануне первой мировой войны. Тяжелые отечественные паровозы типа «ИС», «ФД» и «Л» на них интенсивно применяться не могли без риска повредить рельсовый путь или деформировать переезды. Пропускная способность железных дорог на Западной Украине и в Белоруссии не превышала четырех небольших поездов в сутки, а мосты являлись деревянными и требовали серьезного капитального ремонта. Недоставало шоссейных дорог с твердым покрытием, идущих с востока на запад - их было только две. Аэродромная сеть, первоначально создававшаяся исходя из других стратегических задач и под другие классы самолетов, была досконально была известна абверу. Но вместо того, чтобы строить новую систему базирования военной авиации, рассчитанную на современные самолеты, и радикально модернизировать транспортную структуру, все оставили как есть.

В июле 1939 года при Главном Военном Совете РККА по инициативе заместителя Наркома обороны Г.И. Кулика и начальника Главного автобронетанкового управления Красной Армии Героя Советского Союза Д.Г. Павлова была создана Комиссия по реорганизации танковых и механизированных войск. Оба военачальника утверждали, что существующие бронетанковые корпуса громоздки и управлять ими во фронтовой обстановке трудно. Опыт гражданской войны в Испании с их точки зрения исключал использование танков вне боевых порядков пехоты, из-за чего исчезает необходимость в увеличении их скорости и маневренности. Павлов подверг резкой критике конструкцию быстроходных танков по причине их слабого бронирования вооружения и потребовал прекращения их производства в пользу увеличения серийного выпуска средних трехбашенных танков Т-28Э.

21 ноября 1939 года состоялось правительственное решение о расформировании всех механизированных корпусов и преобразовании их 


\section{5 лет Великой Победы}

в механизированные дивизии в составе 275 танков всех типов - от плавающих пулеметных танкеток T-37/38 до тяжелых гигантов Т-35, - так как принципиально изменялась тактика их применения. Они должны были следовать рассредоточено в боевых порядках наступающих стрелковых подразделений, не маневрируя, чтобы не раздавить бегущих рядом красноармейцев, и в определенных интервалах. В боевых наставлениях четко и недвусмысленно определялись режимы их движения на экономических, малых скоростях при непосредственной поддержке пехоты и конницы, наступающей на укрепленные позиции противника. Из Устава исчезло понятие «механизированный корпус», а командиры танковых дивизий теперь подчинялись командованию округа ${ }^{117}$.

Принципы применения и дислокации боевых кораблей не менялись. Все крупные надводные артиллерийские суда располагались в Балтийском и Черном море. Корабли по-прежнему рассматривались в основном как средство огневой поддержки сухопутных подразделений, высадки десантов морской пехоты и доставки воинских резервов и боеприпасов на блокированные противником базы флота.

Сознавая отставание ВМФ по огневой мощи и дальности хода советских надводных военных кораблей, Советское правительство сумело купить в Германии линейный крейсер «Лютцов» за 100 миллионов золотых марок без вооружения и силовой установки. Корабль привели в Ленинград на буксирах, где он получил название «Петропавловск». Достроить его не успели.

По неверно истолкованному опыту гражданской войны в Испании в военно-воздушных силах РККА ликвидировались специализированные по классам тактические авиационные полки и эскадры, кроме авиачастей ВМФ. В целях лучшей организации взаимодействия боевой авиации с сухопутными войсками все подразделения ВВС были подчинены командующим общевойсковых армий. В каждой общевойсковой армии создавалась смешанная авиационная дивизия (САД), включавшая в себя сразу три-четыре полка: истребительный, легкобомбардировочный (штурмовой), скоростной бомбардировочный и разведывательный, которая выполняла задачи непосредственной воздушной поддержки пехоты и кавалерии. Она стала называться армейской. Сохранялась лишь авиация Главного командования (авиация дальнего действия), фронтовая и войсковая - отдельные разведывательные, корректировочные и связные эскадрильи по одной на каждый стрелковый, механизированный или кавалерийский корпус. Управлять такой массой разнотипных самолетов и обслуживать ее на земле часто оказывалось невозможно для командования ВВС военных округов ${ }^{118}$

С 30 ноября 1939 по 12 марта 1940 года СССР вел войну с Финляндией ${ }^{119}$. Военная кампания закончилась неубедительной победой Красной Армии, но позволила СССР улучшить свои стратегические позиции на северо-западной границе и отодвинуть ее от Ленинграда на 140-200 км. Уроки «зимней войны» заставили новое руководство $\mathrm{HKO}^{120}$ начать восстановление механизированных корпусов. Особенности ландшафта, сказавшиеся на тактике прорыва сильной многополосной обороны «линии Маннергейма» потребовали применения не легких танков, а средних и тяжелых тихоходных машин с противоснарядным бронированием и крупнокалиберным танковыми пушками с высокой начальной скоростью снаряда, которые действовали в боевых порядках наступающей пехоты. В Финляндии лучше всего зарекомендовали средние танки Т-28 с усиленной экранами лобовой броней. Когда советские стрелковые роты под сильным пулеметным огнем закапывались в снег, пропуская свои танки вперед, они в одиночку вели настильный пулеметный огонь. В течение второй мировой войны танкам в таких сложных условиях действовать больше никогда не приходилось. Отчаянные попытки немцев применять танки в Заполярье при неоднократных атаках Мурманска имели гораздо худшие результаты ${ }^{121}$.

На основании приказа НКО СССР от 6 июля 1940 года началось формирование 9 механизированных корпусов и 2 отдельных танковых дивизий. Эта реорганизация не могла не сказаться на их боеспособности. Маршал С.К. Тимошенко издал приказ о формировании в Ленинградском военном округе 1-го механизированного корпуса, который к декабрю уже насчитывал 1011 танков, бронемашин и автомобилей технического обслуживания, то есть вдвое больше положенного по прежнему штатному расписанию.

Разгром французской армии в июне 1940 года радикально изменил геополитическую обстановку в Европе. С оккупацией Франции, Бельгии, Нидерландов, Дании и Норвегии «третий рейх» многократно увеличил свои вооруженные силы, экономический потенциал и приобрел солидную сырьевую базу. В распоряжение вермахта попало стрелковое и артиллерийское вооружение 92 французских, 22 бельгийских, 18 голландских, 12 английских и 6 норвежских дивизий. Во Франции гитлеровцы захватили в качестве трофеев 4930 танков и пушечных бронеавтомобилей, 
Гребенюк А.В.

3 ооо военных самолетов и 3 эскадренных миноносца типа «Фантаск»; в Дании - броненосец береговой обороны «Нильс Юель»; в Нидерландах - эскадренный броненосец «якоб ван Хеемскерк», сразу переоборудованный немцами в тяжелый крейсер ПВО, и подводную лодку О-14. В Норвегии были захвачены два броненосца береговой обороны «Харальд Хаарфагре» и «Торденкельд", 3 эсминца типа "Стег», 3 минных заградителя «Гломан», «Трюгвасон» и «Лауген», подводную лодку В-4 и 35 малых боевых кораблей и торпедных катеров. Все они были введены в состав сравнительно немногочисленных военноморских сил нацистской Германии и начали боевые действия в Северном, Норвежском и Баренцевом море ${ }^{122}$.

И.В. Сталин мгновенно оценил новую международную ситуацию: Красной армии следовало готовиться к скорому отражению агрессии Германии. В июне 1940 года, в Эстонии, Латвии и Литве при поддержке советских войск произошли народные революции, приведшие к свержению «буржуазных правительств». Это произошло сразу после захвата Германией Бельгии, Нидерландов и капитуляции Франции.

Стратегическая обстановка после включения Западной Белоруссии, Западной Украины и прибалтийских республик в состав СССР значительно изменилась. Западная граница за год была отодвинута повсюду на 150-30о км, что равнялось среднему запасу хода немецких танков без дозаправки. Западные области Советского Союза увеличивались на 190 тысяч км², где проживало 12 млн человек.

Краснознаменный Балтийский флот получил постоянный выход в море в любое время года. В его состав были введены эстонские военные кораблиэскадренный миноносец «Сулев» немецкой постройки, 2 колесных деревянных минных заградителя русской дореволюционной постройки «Ристна» и «Суроп», 7 канонерских лодок типа «Лайна», посыльный корабль «Пиккер» и две подводные лодки среднего водоизмещения «Лембит» и «Калев». После капитального ремонта и перевооружения в строй советского ВМФ вошли две латвийские подводные лодки английской постройки «Ронис» и «Спидола» ${ }^{123}$.

В ноябре 1940 года И.В. Сталин, прежде непоколебимый сторонник строительства крупных артиллерийских кораблей, неожиданно согласился утвердить предложение наркома ВМФ Н.Г. Кузнецова об ускорении массового строительства эскадренных миноносцев по проекту № $30 \mathrm{~K}$ «Смелый», № 30 «Осмотрительный» и № 50 «Огненный», и ввода в строй новых вспомогательных военных судов. Указом СНК СССР прекращалась стапельная сборка на всех судостроительных предприятиях линейных крейсеров и линкора «Советский Союз». В КБФ был создан оперативный резерв, или «Невский отряд кораблей» под командованием капитана 1-го ранга В.С. Черокова. В него вошли новые эсминцы «Строгий» и «Стройный», 2 торпедных катера, 3 сторожевых кораблей, 4 бронекатеров, 4 тральщиков, 12 сторожевых кораблей и одна плавучая артиллерийская батарея. Он прикрывал выход из Ладожского озера в Неву.

Учитывая военно-политическое сближение Германии и Финляндии и переброску туда немецких войск, в Ладожское озеро были переведены из Кронштадта старейший балтийский эсминец «Конструктор», сторожевой корабль «Пурга», 5 канонерских лодок, вооруженных тремя 100мм морскими орудиями каждая, и тральщики типа «Ижорец». Параллельно в Лодейном Поле из самоходных грузовых шаланд по опыту гражданской войны стали строиться новые малые мелкосидящие канонерские лодки, вооруженные в основном счетверенными установками пулеметов.

Орудия главного калибра законсервированных линейных крейсеров передавалось Северному флоту. В Заполярье от Архангельска до полуострова Рыбачьего начали энергично устраивать долговременные береговые батареи. С этой целью была сконструирована трехорудийная бетонная стационарная башенная установка, оснащенная 180-мм орудиями с индивидуальным наведением каждого ствола и более совершенными дальномерами и прицелами. В то же время береговая морская артиллерия пополнилась одноорудийными башнями с пушками 356-мм и 406-мм калибра. Их прицельная дальность достигала 2145 километров в зависимости от характера зарядов и калибра орудия, что являлось очень важным фактором для обороны морских коммуникаций ${ }^{124}$.

Для комплектования механизированных корпусов требовались средние и тяжелые танки новой концепции. На Кировском заводе был построен однобашенный танк KB-1, защищенный 75-мм лобовой броней и вооруженный 76-мм пушкой с высокой начальной скоростью снаряда. Одновременно с ним был передан на государственные испытания тяжелый «артиллерийский танк» KB-2, оснащенный 152-мм гаубицей и 102-мм лобовой броней, который стал самой мощной боевой гусеничной машиной в мире, хотя фактически представлял собой самоходную артиллерийскую установку. Оба танка, хотя и имели проблемы с трансмиссией, были приняты на вооружение ${ }^{125}$. Одновременно с ними 


\section{5 лет Великой Победы}

в массовое производство был запущен средний гусеничный танк Т-34.

Началась коренная модернизация авиационного парка ВВС. После XVIII съезда ВКП(б) наркомом авиационной промышленности вместо М.М. Кагановича стал А.И. Шахурин, а его заместителем по опытному самолетостроению - авиационный конструктор А.С. Яковлев. По представлению правительства в 1940 году советским конструкторам самолетов и двигателей А.А. Архангельскому, Н.Н. Поликарпову, С.В.Ильюшину, П.О. Сухому и А.С. Яковлеву без защиты диссертаций Высшая аттестационная комиссия Комитета при СНК присвоила степени докторов технических наук. Ведущие конструкторы самолетов и авиационных двигателей Н.Н. Поликарпову, А.С. Яковлеву, А.А. Архангельскому, В.Я. Климову и А.А. Микулину было присвоено звание Героя Социалистического труда. Все самолетостроители были награждены орденами и представлены к Сталинским и государственным премиям. Серийное производство военных самолетов «устаревших» конструкций прекращалось, и заводы приступали к выпуску новых истребителей и бомбардировщиков. После ареста «уставного догматика», начальника Главного управления ВВС РККА Я.М. Смушкевича в июне 1940 года, И.В. Сталин стал самостоятельно руководить самолетостроением. Приблизив к себе молодого конструктора А.С. Яковлева, он начал тщательно выверять свои представления об оптимальной структуре воздушного флота. Как следовало ожидать, он постепенно восстановил классические идеи П.И. Баранова и С.А. Меженинова. Приоритет штурмовой авиации превратился впоследствии в неповторимую особенность структуры ВВС РККА. Не умаляя титанических усилий конструктора С.В. Ильюшина по принятию на вооружение легендарного самолета Ил-2, отметим, что в это время был реабилитирован командир первой штурмовой бригады Б.А. Туржанский, а многие командиры из этого соединения повышены в должностях и получили назначение в штурмовые полки, пока укомплектованные истребителями-бипланами. Выпуск тяжелых бомбардировщиков Пе8, наоборот, стал сокращаться.

С внедрением в массовое производство новых истребителей МиГ-3, ЛаГГ-з и Як-1, бомбардировщиков Су-2, Пе-2, Ил-4 и Ер-2, и штурмовиков Ил-2 было много организационных и технологических проблем, но они с лихвой окупились в ходе Великой Отечественной войны. Новому начальнику Главного управления ВВС генерал-лейтенанту П.В. Рычагову постановлением Политбюро ЦК ВКП(б) предписывалось сформировать дополнительно к существующим в течение шести месяцев и укомплектовать личным составом и техникой10з авиационных полка.

Нечеловеческим напряжением сил, введя ускоренные сроки обучения курсантов летных училищ, призвав из запаса 10500 выпускников аэроклубов и аттестовав летчиков гражданской авиации призывного возраста, Главное Управление ВВС РККА СССР сумело сформировать 79 смешанных авиационных дивизий и 5 авиационных бомбардировочных бригад. Летно-подъемный состав ВВС РККА увеличился на 80\%, хотя мобилизованные пилоты вынуждены были летать на устаревших самолетах, в том числе взятых из парков авиационных училищ и списанной авиационной техники прибалтийских государств ${ }^{126}$. Командованию ВВС Ленинградского военного округа для формирования новых авиационных полков согласно штатному расписанию не хватало 600 самолетов ${ }^{127}$. Наркомат авиационной промышленности явочным порядком восстановил производство истребителей И-16, так как официально их производство было прекращено. К январю 1942 года заводы Аэрофлота и ремонтные мастерские Осовиахима выпустили 3287 внеплановых самолетов с различными двигателями и вариантами вооружения, которые объявлялись секретными истребителями ${ }^{128}$.

Однако производство новых видов вооружений не сопровождалось изменением боевых уставов и наставлений. «После Халхин-Гола, - вспоминал Герой Советского Союза А.В. Тищенко, - начали широко практиковаться поединки между большими группами истребителей. Эскадрилья мерялась силами с эскадрильей, полк с полком. Результаты этих боев занимали важное место в оценке боеготовности». Умению поражать воздушные цели с рабочих дистанций перестали уделять должное внимание, а искусству индивидуального воздушного боя летчики не обучались. Тактика воздушного боя теперь сводилась к применению горизонтального маневра ${ }^{129}$.

Боевой устав ВВС 1938 года не изменился. Советским летчикам предписывалось экономить моторный ресурс, сберегать материальную часть и летать строем звеньев, повторяя эволюции ведущего. Истребители должны были вести патрулирование на «экономической скорости», составляющей о,6\% максимальной, и на однозначно определенных средних «четных» высотах, что облегчало действия вражеских истребителей и зенитчиков. Скоростные бомбардировщики должны были следовать к цели бомбометания на скорости 0,7\% максимальной на больших высотах. Личным оружием военного пилота в полете теперь 
Гребенюк А.В.

были сабля и пистолетТТ.

Большинство новых авиационных полков не имело необходимого количества летчиков и самолетов. Так, в 240-м истребительном авиационном полку имелось всего 13 истребителей И156ис, 7 летчиков, 25 техников, 8о младших авиационных специалистов, и только штаб полка был укомплектован полностью; 37-й бомбардировочный авиационный полк 31-й САД был укомплектован 22 древними истребителями-бипланами И5, а летчиками были инструкторы аэроклубов ${ }^{130}$. Летно-подъемный состав состоял из инструкторов аэроклубов. Особый 212-й дальнебомбардировочный авиационный полк имел в составе $10 \mathrm{ca}-$ молетов Ил-4. Его летно-подъемный состав состоял из опытных пилотов, мобилизованных из ГВ $\Phi^{131}$.

В строю ВВС РККА к январю 1941 года находилось 17745 боевых самолетов всех классов, произведенных в течение 1938-1941 годов, а 12868 из них размещались в западных приграничных округах. К началу военных действий на советско-германском фронте новых боеспособных самолетов всех классов было в строю 3719 штук ${ }^{132}$. Официальная статистика не учитывала авиационный парк 103 новых авиационных полков и 2850 базовых самолетов морской авиации и гидросамолетов.

Количество самолетов многократно возросло. На приграничных аэродромах с твердым покрытием оказался полуторный комплект истребителей и бомбардировщиков - как старых, так и новых конструкций. Самолеты поэтому были построены в линейки несколькими рядами. Для их рассредоточения требовалось несколько часов. Камуфляжная краска истребителей была сверху темно-зеленой, а двухмоторных скоростных бомбардировщиков - серебристой, что делало их очень заметными с воздуха.

Командование 9-й смешанной авиационной дивизии Западного Особого военного округа, ухитрилось разместить на аэродромном узле Терновое 131 истребитель (66 самолетов МиГ-з и 65 «чаек»). Ранее же польские инженерные войска возвели здесь все необходимые сооружения для постоянной дислокации 30 военных и вспомогательных самолетов.

На аэродроме Долубово базировалось 83 самолета (50 истребителей МиГ-3 и 33 самолета И16) 10-й САД, а на аэродроме Высокий Мазовецк находился 101 истребитель (7о перехватчиков МиГ-3 и 31 самолет И-16) 11-й САД. При этом все коммуникации, ангары, бензохранилища, гаражи, ремонтные помещения и расположение взлетно-посадочных и рулежных полос сохранялись в прежнем состоянии. При всем желании взлететь по тревоге с каждого из аэродромов сумело бы в лучшем случае звено истребителей.

Аэродромов не хватало. Весной 1941 года началось строительство полевых взлетно-посадочных площадок. Казалось бы, появилась возможность если не исправить, то хотя бы улучшить ситуацию с рациональным размещением самолетов. Этого не случилось, потому что командующие ВВС приграничных особых военных округов дважды Герой Советского Союза генерал-лейтенант Г.П. Кравченко, Герой Советского Союза генерал-майор И.И. Копец и Герой Советского Союза генерал-лейтенант Е.С. Птухин единодушно требовали строить их на расстоянии 20-50 км от границы. Необходимые маневры самолетов при взлете и заходе на посадку хорошо просматривались немцами через стереотрубы.

Выкрашенные в черный цвет бензозаправщики и автомобили-стартеры, находившиеся в крестьянских садах, были хорошо видны с воздуха. Маскировочные сети батальонам аэродромного обслуживания не полагались - самолеты должны были находиться «в капонирах или лесных массивах». Капониры построить так и не успели.

К концу 1940 года на западных границах Советского Союза находились всего 3298 танков. И.В. Сталин распорядился сформировать в 1941 году дополнительно к существующим 9 танковым корпусам еще 20 механизированных корпусов.

В механизированном корпусе предусматривалось иметь 36 о6о человек, 1031 танк, 258 орудий и минометов, 5000 автомашин различного назначения, 350 артиллерийских тягачей и 1700 мотоциклов. Такого количества машин просто не было во всех автобронетанковых соединениях РККА на территории Советского Союза. В формируемом 20м механизированном корпусе Западного Особого военного округа насчитывалось 16 танков Т-26, включая двухбашенные пулеметные, в 13-м корпусе - 32 легких танка БТ-7, а в 14-м - 55 танков БТ-5 и 11 машин БТ-2. В составе 14-го корпуса поначалу имелось 30 устаревших легких танков МС1. Материальная часть 24-го механизированного корпуса насчитывала 56 легких танков, из которых половина также нуждалась в ремонте, а 9-го корпуса - 94 машины, среди которых были и тяжелые танки Т-35. Маршал К.К. Рокоссовский, назначенный командующим 9-м механизированным корпусом, вспоминал: «Несчастье заключалось в том, что корпус только назывался механизированным. С горечью смотрел я в походе на наши старенькие танки Т-26, БТ-5 и немногочисленные БТ-7, понимая, что боевых длительных действий они не выдержат. 


\section{5 лет Великой Победы}

Не говорю уже о том, что и этих танков у нас было не более трети положенных по штату. А мотопехота обеих танковых дивизий! Положенных машин у нее не было, но поскольку она значилась моторизованной, дивизия не имела ни повозок, ни коней». Одна боевая укладка на танках БТ-5 и БТ-7 составляла 45 снарядов, а подвозить новые боеприпасы оказалось не на чем ${ }^{133}$.

Спешно формируемый 8-й механизированный корпус КОВО к январю 1941 года был укомплектован только командным и начальствующим составом 34-й кавалерийской дивизии и 7-й стрелковой дивизии. Личный состав был представлен одним комендантским батальоном. Танковые подразделения этого корпуса были представлены ротой малых разведывательных танков Т-37 и батальоном двухбашенных танков Т-26, мобилизованных из Киевского танкового училища. К весне 1941 года ситуация изменилась в лучшую сторону, так как в западные военные округа поступили 243 танка КВ-1, 115 танков Т-34, 6о легких танков Т50 и 670 танков Т-40 и Т-40С. Все они распределялись по механизированным корпусам пропорционально количеству устаревших танков. Так, в составе 1-го и 10-го механизированных корпусов Ленинградского военного округа имелось всего шесть КВ-1 и восемь Т-34 $4^{134}$.

Ответ на вопрос, зачем понадобились И.В. Сталину «потемкинские» механизированные корпуса и новые авиационные полки, лежит на поверхности. Необходимо было заставить германский Генеральный штаб перенести сроки вторжения, так как резиденты абвера считали эти новые подразделения полностью укомплектованными воинскими соединениями. «Определить хотя бы приблизительно военную мощь Советского Союза было почти невозможно, - пишет К. Типпельскирх. - Слишком многие факторы, из которых при нормальных условиях можно было бы составить сложную картину мобилизационных возможностей вооруженных сил и их экономических источников, были покрыты непроницаемой тайной. На протяжении двадцати лет Советский Союз, отгородившийся уже тогда железным занавесом от остального мира, жил своей особой жизнью.... О достигнутых успехах всякого рода ежегодно соо6щалось лишь в сравнительных процентах, а не в абсолютных величинах... Советский Союз подготовился к вооруженному конфликту, насколько это было в его силах. На стратегическую внезапность германское командование не могло рассчитывать. Самое большее, чего можно было достигнуть, - это сохранить в тайне срок наступления, чтобы тактическая внезапность облегчила вторжение на территорию противника» ${ }^{135}$.
Союзники «третьего рейха» выдвинули к советским границам наиболее боеспособные воинские подразделения: Финляндия - 18 пехотных дивизий, Румыния - 12 пехотных, 4 кавалерийских и 1 танковую дивизии, 3 горно-пехотные и 2 крепостные бригады; Венгрия - 2 моторизованные и 1 кавалерийскую бригады; Словакия - 2 пехотные дивизии и 1 кавалерийскую бригаду; а Италия 3 моторизованные дивизии ${ }^{136}$. По состоянию на 22 июня 1941 года силы немецко-фашистские подразделения насчитывали 5 млн 500 тысяч офицеров и солдат вермахта против 2 млн 680 тысяч военнослужащих РККА. Еще 6 вспомогательных дивизий СС были сформированы этническими немцами из оккупированных государств. В советской историографии они обычно не учитывались, поскольку им приходилось выполнять будто бы вспомогательные задачи охраны коммуникаций. Но в маневренной войне такие функции являются важнейшим фактором победы наступающих войск первого эшелона, и эти соединения играют роль оперативного резерва. На советско-германской границе находились в первом и втором эшелоне 1100 французских танков Гочкис Н.39, 730 танков Рено R.35 и FCM.36, 297 танков Сомма S.35, и 722 чехословацких танка 360 LT.35, и 352 LT.38. Наряду с ними во вторжении в Советский Союз участвовали 179 венгерских танков «Толди» и LT.38, 137 финских танка T-26, T37/38 и Виккерс Mk.VIE, 124 румынских танка LT.38 и ЧКД R.1, 56 итальянских танка L.3/33 и L.6/40 и 40 словацких танков LT.38 $8^{137}$. Уже в ходе первого танкового сражения под Луцком, Дубно и Бродами в июне 1941 года большая часть из них была введена в 6 ̆й $^{138}$. Большинство танков и самолетов противника по своим тактико-техническим характеристика и эксплуатационным качествам уступали образцам советской военной техники в западных военных округах, превосходя их, однако, в тактике боевого применения.

По причине увеличения протяженности западной границы 173 стрелковых, кавалерийскихи моторизованных дивизий и бригад РККА вынуждены были равномерно расположиться в два эшелона согласно «Плану прикрытия границы 1941 года» по всей ее линии, не имея возможности сконцентрироваться на уязвимых направлениях. Но ни одно соединение не было укомплектовано по полному штату: 144 дивизии имели численность по 8 тысяч человек, 19 - от 600 до 5 тысяч и 7 кавалерийских дивизий - в среднем по 6 тысяч человек ${ }^{139}$. Между Таллинном и Ленинградом на побережье вообще не было никаких регулярных сухопутных войск. Таким образом, к 22 июня советскому Главному Командованию 
Гребенюк А.В.

не удалось создать исходной стратегической группировки Красной Армии у западных границ в том ее виде, которого требовала реально складывавшаяся обстановка. Это в значительной мере и определило неблагоприятное для СССР соотношение сил в приграничной полосе к началу войны $^{140}$. Неудачи PKКА, оснащенной любой техникой, произошли бы непременно, хотя и с меньшими людскими и территориальными потерями.

Верховное командование вермахта сумело создать временное превосходство и блокировать кадровые подразделения Красной армии в местах их дислокации. Не имея количественного преимущества в наступательных вооружениях, Генеральный штаб Германии компенсировал его созданием многократного превосходства личного состава полевых соединений на главных направлениях. Вся бомбардировочная авиация армии вторжения совершила в первые три часа грандиозный налет на цели в западных областях СССР, причем уничтожению военных и промышленных объектов в полетных заданиях отводилось гораздо меньше места, нежели бомбежке городов и крупных населенных пунктов. Паника среди мирного населения должна была привести к дезорганизации инфраструктуры приграничных военных округов. В известной мере это удалось.

Гитлер не учел, что в случае провала «блицкрига», немецко-фашистские войска окажутся очень уязвимыми. В отличие от Советского Союза, военно-промышленный комплекс «тысячелетнего рейха» производил исключительно те виды вооружений, которые были необходимы для осуществления ограниченных во времени наступательных операций. Продолжительная война для Германии была чревата катастрофой, так как соответствующих типов серийной бронетанковой техники - тяжелых танков и самоходных установок, тяжелых бомбардировщиков и высотных истребителей-перехватчиков в структуре вермахта не только не имелось, но и не проектировалось. В свою очередь, оборонная промышленность СССР их конструировала и производила. Этот факт, наряду с беспримерным героизмом бойцов и командиров Красной армии, непредсказуемыми для оккупантов операциями партизан и самоотверженным трудом рабочих и инженеров в тылу, стал одним из важнейших в достижении победы над гитлеровской Германией.

Andrey V. Greben'uk. Workers' and Peasants' Red Army on the eve of the Great Patriotic War

The article deals with the military technical posture of the Red Army on the eve of the Great Patriotic War. The author discusses the problems, which were encountered by the military and political leaders of the USSR trying to undertake military reforms and also the mistakes made by the Soviet leaders in transforming the Red Army.

\section{Keywords}

Workers' and Peasants' Red Army, plans of development of military posture, Great Patriotic War

Великая Отечественная война

1. Кукель В.А. Правда о гибелиЧерноморского флота в 1918 году. Пг., 1923; См. Пїдлуцький О. Загибель ескадри // Дзеркало тижня. 2001. № 13 С. 7-9.

2. Хорьков Г.И. Советские надводные корабли в Великой Отечественной войне. М., 1981. С. 7-11.

3. Козлов И.А., Шломин В.С. Краснознаменный Северный флот. М., 1977. С. 17-18.

4. Соболев А.А. Красный флот в гражданской войне 1918-1920 гг. М., 1924. С. 6-10.

5. Золотарев В.А., Шломин В.С. Как создавалась военно-морская мощь Советского Союза. СПб, 2004. Кн. 1. С. $221-232$.

6. Хайрулин М.В., Кондратьев В.И. Военлеты погибшей империи: авиация в гражданской войне. М., 2007. С. 15-19.

7. Жаров Ф.И. Подвиги красных летчиков. М., 1963. С. 155-156.

8. автарадзе А.Г. Военные специалисты на службе республике Советов. М., 1988. С. 170-177.

9. Амирханов Л.И. Броненосцы железных дорог. СП6, 2005; Коломиец М.В. Бронепоезда Красной Армии. М., 2005.

10. Барятинский М.Б., Коломиец М.В. Бронеавтомобили «Остин». СПб, 2001.

11. Groehler O. Geschichte des Luftkriegs 1910 bis 1980. Berlin, 1981. S. 107.

12. Павлов И.У. Боевой путь. М., 1938. С. 169-170.

13. Красовский С.А. Жизнь в авиации. М., 1960. С. 55-56.

14. Ткачев В.М. Вопросы тактического применения авиации в маневренной войне. Чита, 1921. С. 28-49.

15. Спатарель И.К. Против «черного барона». М., 1967. С. 199-202.

16. Березин П.Ф. Красная авиация в борьбе с белополяками. М., 1940. С. 38.

17. Шиуков А.В. Война в воздухе. М., 1939. С. 36-39.

18. Łydżba Ł. II Wielkopolska Eskadra Lotnicza (13 Eskadra Myśliwska) // Lotnictwo z szachownicą. № 7.

19. Андерс В. Без последней главы // Пер. с польского. Иностранная литература. 199о. № 11. С. 231.

20. Lincoln B.W. Armageddon: the Russians in War and Revolution. N.Y., 1986. 


\section{5 лет Великой Победы}

21. РГВА. Ф. 27. Д. 673. Оп. 1. Л. 1-22.

22. Антонов А.С., Артамонов Б.А., Коробков Б.М., Магидович Е.И. Танк. М., 1954; Коломиец М.В., Мощанский И.Б., Ромадин С.В. Танки гражданской войны. М., 1999.

23. Косырев Е.А., Орехов Е.М., Фомин Н.Н. Танки. М., 1973. С. 31-32.

24. Свирин М.Н., Бескурников А.А. Первые советские танки. М., 1995. С. 9-12.

25. Радзиевский А.И. Танковый удар. М., 1977. С. 13-21.

26. РГВА. Ф. 66. Д. 71. Оп. 1. Л. 1-8.

27. Каминский М.Н. В небе Чукотки: записки полярного летчика. Магадан, 1967. С. 277.

28. Протоколы одиннадцатого съезда РКП(6). М., 1936. С. 604-6о5.

29. Спирин И.Т. В голубом небе. М., 1960. С. 79.

3о. Фрунзе М.В. Избранные произведения. М., 1960. С. 234.

31. Джордж-Ллойд Д. Правда о мирных договорах / Пер. с английского. М., 1957. Т. 1. С. 350.

32. Виноградов С.Е., Федечкин А.Д. «Рюрик»- флагман Балтийского флота». Л., 2003.

33. Ленин В.И. Полн. собр. соч. Т. 45. С. 311-312.

34. Усов В.Ю. Эскадренный миноносец «Новик». М., 2001; Чернышев А.А. «Новики»: лучшие эсминцы Российского Императорского флота. СПб, 2007.

35. Ананьин И.А. Корабли нашей юности. Л., 1976. С. 12-17.

36. Бронепалубный крейсерЧерноморского флота «Память Меркурия» после установления на Украине власти Центральной рады был переименован в «Гетман Иван Мазепа»; позже он назывался «Иван Скоропадский», потом - «Богдан Хмельницкий», в 1923 году по решению РВС СССР стал именоваться «Коминтерном», а в 1943 году превратился в минный заградитель «Красный Крым». - Прим. автора.

37. Варгин Н.Ф. Флагман флота Кожанов. М., 1980. С. 67.

38. Симаков Б.Л., Шипилов И.Ф. Воздушный флот страны Советов. М., 1958. С. 170.

39. Ленин В.И. Полн. собр. соч. Т. 53. С. 330.

40. РГВА. Ф. 203. Д. 28. Оп. 2. Л. 3.

41. Меженинов С.А. Огородников С. Ф. Вопросы применения и организации авиации. М., 1924; Его же. Очерки по вопросам авиации. М., 1925; Его же. Основные вопросы применения военных воздушных сил. М., 1926; Его же. Воздушные силы в войне и операции. М.-Л., 1927.

42. Тимофеев В.А. Товарищи летчики. М., 1963. С. 102-123.

43. ГАРФ. Ф. 70. Д. 104. Оп. 2. Л. 1-7.

44. Schmitt G. Hugo Junkers - von Rapallo bis Fili // Flieger-Jahrbuch 1985/86. S. 104-108.

45. Мухин М.Ю. Авиапромышленность СССР в 1921-1941 годах. М., 2006. С. 112.

46. Гордон Е.И., Зенкин В.Н., Титов В.Г. Истребители-бипланы Поликарпова. М., 1992.

47. Němeček V. Suchoj I-4 // Letectvi a kosmonautika, 1977. № 21. S. 28-30.

48. Дьяков Ю.Л., БушуеваТ.С. Фашистский меч ковался в СССР. М., 1992.

49. РГВА. Д. 375. Оп. 2. Л. 162-163; Петров В., Тихонов Ю. Советский полигон Люфтваффе // Родина. 2004. № 1. С. 135; Кантор Ю. Заклятая дружба: секретное сотрудничество СССР и Германии в 1920-1930-е годы. СП6, 2009. C. 78-79; Seidt H.U. Berlin, Kabul, Moskau: Oskar Ritter von Niedermayer und Deutschlands Geopolitik. Munchen, 2003. S. 213.

50. Крылатое племя: воспоминания о советских летчиках трех поколений. М., 1962. С. 45-46.

51. Триандафиллов В.К. Характер операций современных армий. М.-Л. 1929. С. 54, 134-135.

52. Калиновский К.Б. Танки в группах ДД // Механизация и моторизация армии. 1931. № 2. С. 7-9.

53. Гальдер Ф. Дневник начальника Генерального штаба сухопутных войск Германии / Пер. с немецкого. Т. 1. М., 1962. С. 287, зо1.

54. ГАРФ. Ф. 2097. Оп. 1. Д. 1051. Л. 35.

55. Цит. по Němeček V. Tupolev ANT-3 // Letectvi a kosmonautika. 1973. № 18. S. 29.

56. The Flight.1929. № 21. Р. 133.

57. Ригмант В.Г., Котельников В.Р. Тяжелый бомбардировщик ТБ-1. М., 2001.

58. Глуховский С.И. Когда вырастали крылья. М., 1965. С. 129-130.

59. П.И. Баранов погиб в 1933 году при неясных обстоятельствах. Советские центральные газеты сообщили: «5 сентября в 9 час. 20 мин. южнее Подольска, около станции Лопасня, в результате аварии самолета погибли: заместитель Наркомтяжпрома, начальник Главного управления авиационной промышленности т. Баранов П.И., начальник Главного управления гражданского воздушного флота т. Гольцман А.З., директор завода № 22 т. Горбунов С.П., зам. начальника Главного управления гражданского воздушного флота т. Петров А.В., член Президиума Госплана СССР т. Зарзар В.А., шеф-пилот т. Дорфман И.М., бортмеханик Плотников Н.Е. и т. Баранова Б.М. Правительство назначило семьям погибших персональные пенсии». -Прим. авmopa. 
Гребенюк А.В.

6о. См. подробнее: Маслов М.А. ТБ-з: воздушный суперлинкор Сталина. М., 2007.

61. Кондратьев П.В. Полет сквозь годы. М., 1970. С. 192.

62. См. подробнее: НобилеУ. Красная палатка: воспоминания о снеге и огне / Пер. с итальянского. М., 1975.

63. Gunston B. Allied Fighters of World War II. London. 2000. P. 85.

64. Фрунзе М. В. Избранные проведения. М., 1951. С. 286, 287.

65. См. подробнее: Цветков И.Ф. Гвардейский крейсер «Красный Кавказ». Л., 1989; Залесский Н.А. Еще раз о крейсерах типа «Светлана» // Морской сборник. 1999. № 10-12; Скворцов А.В. Гвардейский крейсер «Красный Кавказ». М., 2005.

66. Цветков И.Ф. Линкор «Октябрьская революция». Л., 1983; Скворцов А.В. Линейные корабли типа «Севастополь». СПб, 20о6; Васильев А.А. Линейные корабли типа «Марат». СПб, 2007.

67. Чернышев А.А. Крейсеры типа «Киров». М., 2001.

68. Мельников Р.М. Крейсеры типа «Очаков». Л., 1986.

69. Кузнецов Н.Г. Накануне. М., 1966. С. 259.

70. Васильев А.А. Линейные корабли типа «Советский Союз». М., 2006.

71. См. подробнее: Михайлов А.А. Линейные корабли типа «Ройял Соверен». М., 2002.

72. См. подробнее: Качур П.И. Лидеры типа «Ленинград». СПб, 2007.

73. РГВМА. Ф. 1678. Д. 67. Л. 180-184; Ф. 3-970. Д. 236. Л. 2.

74. Лихачев П.В. Эсминцы типа «Новик» в ВМФ СССР. СПб, 2005

75. Морин А.Б. Эскадренные миноносцы типа «Гневный». СПб, 2001.

76. Балакин С.А. «Гремящий» и другие эскадренные миноносцы проекта № 7. СП6, 1996.

77. Эскадренные миноносцы проектов № 7 (однотрубные) и № 7 (двухтрубные) имели конструктивные недостатки, в частности, недостаточную прочность корпусов в сегменте 136-го шпангоута. По этой причине во время шторма на Баренцевом море в июле 1942 году переломился на волне эсминец «Сокрушительный»-Прим. автора.

78. См. подробнее: Кулагин К.Л., Морозов М.Э. Подводные лодки типа «Щ». СПб, 2004

79. См. подробнее: Игнатьев Э.П. Подводные лодки «М». СПб, 1996.

8о. Балакин С.А., Морозов М.Э. Подводные лодки типа «С». СПб, 2002.

81. Эверит Д. Подводные лодки типа «К». Пер. с английского. М., 2003.

82. См. подробнее: Трусов Г.М. Русские и советские подводные лодки. Самара, 2006.

83. См. подробнее: Платонов А.П. Несостоявшиеся «авианосные» державы. СПб, 1999.

84. См. подробнее: Мостовенко В.Д. Танки. М., 1956; Солянкин А.Г., Павлов М.В., Павлов И.В., Желтов И.Г. Советские легкие танки. 1920-1941 гг. М., 2007.

85. Свирин М.Н., Бескурников А.А. Первые советские танки. М., 1995. С. 22-26.

86. Барятинский М.Б. Легкий танкТ-26. М., 2002.

87. Барятинский М.Б., Коломиец М.В. Легкие танки БТ-2 и БТ-5. М., 1996.

88. Барятинский М.Б., Коломиец М.В. Легкий танк БТ-7. М., 2005.

89. Кощавцев А.И., Князев М.В. Легкий танк Panzer.I. М., 2001.

9o. Федосеев С.П., Коломиец М.В. Легкий танк Pz.Kpfw.II. М., 2007.

91. Коломиец М.В., Мощанский И.Б. Средний танк Т-28. М., 2001.

92. Коломиец М.В., Свирин М.Н. Тяжелый танк Т-з5: сухопутный дредноут Красной армии. М., 2007.

93. Астров Н.А. Из воспоминаний // За рулем. 1989. № 9. С. 22.

94. Мощанский И.Э. Советские легкие танки Т-зо, Т-40, Т-40С. М., 2007.

95. Чубачин А.В. Легкий танк Т-50. М., 2007.

96. Баран Я.Н. Так родилась тридцатьчетверка //Т-34: Путь к победе. Киев. 1989. С. 58-66.

97. Павлов М.В., Павлов И.В., Желтов И.Г. Советские средние танки довоенного периода (1924-1941). М., 2000. С. 44-49.

98. Солянкин А.Г., Павлов М.В., Павлов И.В., Желтов И.Г. Советские самоходные артиллерийские установки (1921-1941). М., 20о8.

99. См. подробнее: Барятинский М.Б. Бронеавтомобили Красной Армии в 1918-1945 гг. М., 2003; Коломиец М.В. Средние бронеавтомобили Красной Армии. М., 2003.

100. Rossinsky G. German Air Power // New York Times. 1941. 10 June.

101. РГВА. Ф. 9. Оп. 29. Д. 482. Л. 4, 11-13.

102. РГВА. Ф. 4. Оп. 15. Д. 13. Л. 232-237.

103. См. подробнее: Ветров А.А. Волонтеры свободы. М., 1978.

104. См. о нем: Иссерсон Г.С. Судьба полководца // Дружба народов. 1988. № 5 .

105. См. подробнее: Кербер Л.Л. Туполевская шарага. СПб, 1999.

106. Дроговоз И.Г. Большой флот страны Советов. Минск, 2003. С. 43

107. Кузнецов. Накануне. М., 1966. С. 229.

108. См. подробнее: Хазанов Д.Б. 1941. Горькие уроки: война в воздухе. М., 2006. 


\section{5 лет Великой Победы}

109. Яковлев А.С. Цель жизни. М., 1980. С. 389

110. Грабин В.Г. Оружие Победы. М., 1989. С. 333.

111. Ванников Б.Л. Записки наркома // Знамя. 1988. № 1. С. 124-125.

112. Асмоловский С.В. Легкий танк Pz.Kpfw.38(t) «Прага». М., 2004

113. Черчилль У. Вторая мировая война / Пер. с английского. Т. 1. М., 1991. С. 317-319.

114. Ротмистоов П.А. Время и танки. М., 1972. С. 84.

115. Сандалов Л.М. Пережитое. М., 1961. С. 42-43.

116. Черчилль У. Вторая мировая война / Пер. с английского. Т. 2. С. 205.

117. Боевой устав танковых войск Красной Армии. Ч. 1. М., 1940.

118. Андреев А., Синикчиянц А. Чему учат уроки прошлого // Вестник воздушного флота. 1996. № 7-8. С. 14-16.

119. Семиряга М.Н. Советско-финляндская война 1939-1940 гг. М., 1991; Советско-финская война 1939-1940 гг. Сборник статей. Минск, 1999.

120. 8 мая 1940 года маршал К.Е. Ворошилов был освобожден от должности Народного комиссара обороны. В должность наркома вступил маршал С.К. Тимошенко. Начальником Генерального штаба стал генерал армии К.А. Мерецков, начальником Главного автобронетанкового управления - генерал-лейтенант танковых войск Н.Я. Федоренко, начальником Главного артиллерийского управления - генерал-лейтенант артиллерии Н.Д. Яковлев, начальником Главного управления ВВС - генераллейтенант авиации Я.М. Смушкевич.

121. Архипов В.С. Время танковых атак. М., 2009. С. 84.

122. Вторая мировая война на море / Под. ред. Е.А. Тараса. Минск, 2002. С. 84-92.

123. Ананьин И.А. Корабли нашей юности. Л., 1976. С. 188.

124. Головко А.Г. Вместе с флотом. М., 1984. С. 211.

125. Сергеев П.Н. КВ-1. М., 2004; Тяжелый танк КВ-2 «Гигант» / Пер. с английского. М., 2004.

126. SpencerT. Gloster Gladiator. London, 2003. P. 86; Lietuvos Aviacijos Istorija 1919-1940 m. Kaunas, 2008. S. 197.

127. Шепелев А.Л. В небе и на земле. М., 1974. С. 178.

128. Голубев В.М. Крылья крепнут в бою. М., 1976. С. 193.

129. Тищенко А.В. Ведомые «Дракона». М., 1966. С. 58.

130. Руденко С.И. Крылья Победы. М., 1976. С. 267.

131. Богданов Н.Г. В небе - гвардейский Гатчинский: из записок летчика АДД. Л., 1980. С. 41.

132. Шумихин В.С. Советская военная авиация 1917-1941 гг. М., 1986. С. 387-388.

133. Рокоссовский К.К. Солдатский долг. М., 1985. С. 199-200.

134. Анфилов В.А. Дорога к трагедии сорок первого года. М., 1997

135. Типпельскирх К. История второй мировой войны. М., 2002. С. 238-239.

136. Там же. С. 233-237.

137. Такер-Джонс Э. Великий танковый грабеж: трофейная броня Гитлера / Пер. с английского. М., 2008.

138. Былинкин С.Н. Танковое сражение под Бродами - Ровно. 1941. Смоленск, 2006; Исаев А.В. Дубно - 1941. Величайшее танковое сражение второй мировой войны. М., 2009.

139. Василевский А.М. Дело всей жизни. М., 1987. С. 103-104.

140. Начальный период войны: по опыту первых кампаний и операций второй мировой войны: сб. статей / Под. ред. С.П. Иванова. М., 1974. С. 210-211. 